pag

Business School

WORKING PAPER SERIES

\begin{tabular}{l|l} 
Working Paper & $\begin{array}{l}\text { Interactions Between Risk-Taking, } \\
\text { Capital, and Reinsurance for Property- } \\
\text { Liability Insurance Firms }\end{array}$ \\
& $\begin{array}{l}\text { Selim Mankaï } \\
\text { Aymen Belgacem }\end{array}$
\end{tabular}

http://www.ipag.fr/fr/accueil/la-recherche/publications-WP.html

IPAG Business School

184, Boulevard Saint-Germain

75006 Paris

France 


\title{
Interactions Between Risk-Taking, Capital, and Reinsurance for Property-Liability Insurance Firms
}

\author{
Selim Mankai ${ }^{\mathrm{a}}$, Aymen Belgacem ${ }^{\mathrm{ab}}$
}

March, 2013

\author{
${ }^{a}$ IPAG Business School, Paris \\ ${ }^{\mathrm{b}}$ Université d'Orléans, LEO-UMR 7322
}

\begin{abstract}
:
Theory and empirical evidence recognize interactions between capital and risk. This paper analyzes the effect of reinsurance, as a new endogenous decision variable, on this policy mix using simultaneous equations model. Empirical results obtained from a sample of U.S. property-liability insurance firms reveal significant interactions between capital, risk, and reinsurance. The relationship between risk and capital is positive, highlighting the effectiveness of regulatory mechanisms. Reinsurance is negatively associated with capital, for which it appears to act as a substitute. These results are strongly sensitive to the level of capital held in excess of the regulatory minimum requirements. Weakly capitalized firms adjust their reinsurance and risk levels more extensively and try to rebuild an appropriate capital buffer. Unlike other decision variables, the capital ratio converges toward a target level.
\end{abstract}

Keywords: Risk-taking, Capital Regulation, Reinsurance, Simultaneous Equations, Instrumental Variables.

JEL Classification: G22, G28, G32 


\section{Introduction}

Insurance firms have always been subject to various constraints with respect to risk-taking and capital holding. Since its introduction in 1994, the risk-based capital (RBC) system has steadily consolidated the interdependence between these two decisions (Cheng and Weiss, 2012). Capital adjustments are generally made through earning retention or new shares issuance. Hoerger et al. (1990) and Garven et al. (2003) demonstrate that reinsurance indirectly affects these adjustments by reducing risk and acting as contingent capital. Wells et al. (1995) find that mutual insurers use reinsurance to reduce funding difficulties. Moreover, the broad adoption of the Enterprise Risk Management (ERM) framework further strengthens the links between risk-taking, capital, and reinsurance (Nocco and Stulz, 1996). Similarly, recent regulatory changes are more amenable to defining capital requirements in terms of certain qualitative aspects of reinsurance (Holzmüller and Eling, 2008 and Scordis and Steinorth, 2012). Understanding the interactions between capital, risk and reinsurance is of great relevance, particularly for regulators, who must craft prudential rules for regulating insurers' behavior ${ }^{1}$. Shareholders are also concerned by the possible transmission of shocks to capital, resulting from unanticipated losses. Negative shocks often entail forced liquidations of assets, which adversely affect the firm value.

Among the relationships between the three decision variables considered here, those between capital and risk are by far the most studied in the literature. Several hypotheses related to moral hazard, agency costs and regulatory pressures have been advanced to explain the interactions between them. A first hypothesis, based on agency costs and buffer capital theory, predicts a positive relationship between capital and risk. An alternative hypothesis, based on information asymmetry regarding the activation of the guarantee fund in case of bankruptcy, predicts a negative relationship. The conflicting predictions of these hypotheses have led to active empirical research. Shrieves and Dahl (1992) were the first to examine this issue for U.S. banks. In a subsequent paper, Cummins and Sommer (1996) investigate the issue for non-life insurance firms, providing empirical support for a positive relationship between capital and risk. Baranoff and Sager (2002) empirically explore these interactions in the case of life insurance, finding a positive (negative) relationship between capital and asset (liability) risk. Recent studies, such as Shim (2010) and Cheng and Weiss (2012), also confirm a positive relationship between these variables.

Although this relationship between capital and risk has been extensively studied in the literature, few papers to date have explored the relationship between risk and reinsurance and even less, the interactions between capital and risk with reinsurance. There are several reasons to believe that reinsurance is endogenously influenced by the choice of capital and risk and vice versa. MacMinn (1987) and Plantin (2006) find that reinsurance is determined jointly with capital structure. Dionne and Triki (2004) document a strong positive relationship between leverage as a risk indicator and reinsurance demand. Shiu (2011) focuses on the endogenous nature of reinsurance and finds that the latter is positively related to leverage, and vice versa. All of these results support the hypothesis of interdependence between reinsurance, capital, and risk.

This study analyzes capitalization policy and its relationship to risk-taking and reinsurance. More specifically, we aim to determine the nature of adjustments between these decision variables and whether they converge toward target levels. To this end, we use a simultaneous equation system, which considers their potential endogeneity. The contribution of this paper to the existing literature is twofold: First, we try to fill in the gap in the literature by examining the interactions among these three decision variables instead of studying them in pairs. We believe that much is to

\footnotetext{
${ }^{1}$ The theoretical literature often provides conflicting answers to these questions (Scannella, 2012). Strict regulation may create distortions in the operations of solvent firms. In contrast, permissive regulations may lead to high-risk exposure, threatening the creditworthiness of insurers. This situation often implies a slowdown in innovation, inefficient investment strategies, or passive capital accumulation.
} 
be gained through a joint analysis of the three decision variables. The second motivation of the paper is that most of previous studies (e.g. Cole et al. 2011; Shim, 2010, Shiu, 2011) argue that interactions differ according to several transversal variables such as the size, the organizational form and the group affiliation. This led us to perform a subsample analysis in the second part of the paper.

Our empirical results confirm this hypothesis and show that the capital, risk and reinsurance interact in both directions. The subsample analysis shows that weakly capitalized insurers try to build an adequate capital buffer by increasing capital and reducing risk. In contrast, those with large capital buffers tend to increase both risk and reinsurance demand. We provide empirical evidence that the capital ratio converges slowly toward a target level.

This paper is organized as follows. Section 2 sketches the theoretical underpinnings of the potential interactions between risk-taking, capitalization, and reinsurance and develops a set of hypotheses. Section 3 identifies and discusses the main determinants of each decision. Section 4 presents our econometric model specification and estimation techniques. Section 5 describes our sample and provides summary statistics. Section 6 analyzes our empirical results and provides some robustness checks. Section 7 provides some concluding remarks.

\section{Theoretical background and research hypothesis}

In this section, we briefly outline the theoretical literature that highlights the interactions between capital, reinsurance, and risk-taking and posit the hypotheses used in our empirical analysis.

\subsection{Interactions between capital and risk}

Interactions between capital and risk have been the focus of active research, particularly in the banking sector. The introduction of RBC appears to reinforce the interdependence between these two decisions which are interconnected under the influence of several factors, such as agency costs, moral hazard, and regulatory pressure. The literature makes contradictory predictions regarding the nature of such interactions. A first hypothesis predicts a negative relationship between risk and capital, reflecting insurers' incentives to exploit guarantee fund in case of failure, given that insolvency costs will be borne by guaranty fund members. When contribution in the fund is not correlated with actual risk, i.e. flat rather than risk-based premiums, this opportunity can create adverse incentives in insurance markets and encourage insurers to increase risk and reduce capital and thus, take advantage of the moral hazard posed by the guaranty fund system (Cummins, 1988; Horiuchi and Shimizu, 2001, Cheng and Weiss, 2012). However, the relevance of this hypothesis is tempered by the fact that the coverage of the guarantee fund is less complete than in the banking sector and by the growing effectiveness of supervisory mechanisms and market discipline (Cheng and Weiss, 2012). Therefore, the incentive to take excessive risk for non-life insurers is restrained. Another explanation for a negative relationship between capital and risk for U.S insurers may be due to flaws in the RBC formula. Cheng and Weiss (2012) argue that some types of risk are overweighting, while others are underweighting. This encourages insurers to rearrange their portfolios by choosing assets or lines of business with low weights. Then insurer risk would have increased while capital requirements would have decreased, resulting in a negative relationship.

A second hypothesis suggests a positive relationship between these two variables. According to capital buffer theory, insurers hold an excess capital above the regulatory minimum as a guarantee against unanticipated extreme losses and in order to avoid regulatory costs (Shim, 2010). This relationship between capital and risk is more pronounced in the short run than in the long run (Jokipii and Milne, 2011) and it also depends on capital level. Specifically, insurers with acceptable levels of capital may not respond to the RBC requirements and may even increase their risk level. 
However, those with relatively low capital levels try to build a capital buffer by raising capital or reducing risk and respond strongly to regulatory pressure and market discipline. Fonseca and Gonzalez (2010) argue that market discipline can further affect the recapitalization decision. Thus, insurers exposed to strong market discipline are incentivized to adjust their capital more quickly. Therefore, our first hypotheses are as follows:

$$
\begin{aligned}
& \mathrm{H}_{1 \mathrm{~A}} \text { : Capital and risk adjustments are positively related. } \\
& \mathrm{H}_{1 \mathrm{~B}} \text { : Weakly-capitalized insurers adjust their capital and risk more quickly than highly-capitalized insurers. }
\end{aligned}
$$

\subsection{Interactions between capital and reinsurance}

Shiu (2011) argues that there is a relationship in both directions between reinsurance and capital structure and thus, they might be jointly determined. Under the renting capital hypothesis, reinsurance is typically viewed as a substitute for capital (Armstrong and Dror, 2007). Stulz (1996) and Adiel (1996) demonstrate that reinsurance affects solvency and can function as off-balance sheet capital. In addition, reinsurance increases the insurer's surplus and strengthens its underwriting capacity (Graham and Rogers, 2002 Aunon-Nerin and Ehling, 2008, Zou and Adams, 2008, Bartram, Brown and Fehle, 2009). Transferring risk to a reinsurer relaxes capital restrictions for an insurer and allows expanding its capacity to issue new policies. Thus, this risk transfer means reduces the required capital on the insurer's balance sheet by enabling it to use capital 'rented' from the reinsurer. Using traditional sources of capital, such as corporate debt, contingent capital, or new equity, in response to a shock is typically an expensive and difficult operation. Thus, Insurers prefer using reinsurance than holding more capital as it allows them to maintain an acceptable level of solvency. On the other side, according to the bankruptcy-cost argument, highly leveraged insurers are more exposed than others to risk of insolvency. Thus, reinsurance protects them against unexpected losses and reduces the risk of insolvency (Shiu, 2011). Thus, our third hypothesis is as follows:

\section{$\mathrm{H}_{2}$ : There is a negative relationship between capital and reinsurance in both directions.}

\subsection{Interactions between reinsurance and risk}

One way to reduce volatility, insolvency and/or specific risk and thus capital requirements is to use reinsurance, especially when risk level moves closer to solvency constraints (Adams, 1996). Agency theory suggests a positive relationship between risk-taking and reinsurance. Excessive risktaking limits the ability of insurers to retain projects with positive net present value. Reinsurance is thus a way of mitigating this problem by transferring part of the risk to reinsurers. In addition, reinsurance can play the same role as the guarantee fund and encourage insurers to take on more risk or reduce capital. Because reinsurers have an incentive to monitor the underwriting risk of the insurers with whom they do business (Cole et al. (2011), this relationship between risk and reinsurance is more pronounced for affiliated rather than for nonaffiliated reinsurers due to the costs of monitoring which are more important for the latter.

Thus, we formulate the following hypothesis:

\section{$\mathrm{H}_{3}:$ Risk and reinsurance adjustments are positively related.}




\subsection{Impact of transversal factors}

\section{Size}

The neoclassical theory of the firm identifies several factors that may affect the main financial decisions of insurers. Within this context, size plays an important role in influencing the insurer's risk appetite through its effect on investment opportunities, the firm's demand for reinsurance, and the firm's access to capital. Large firms are generally subject to low information asymmetry between managers and potential investors, which reduces the cost of capital (Smith, 1977). Moreover, they are likely to have a better qualitative and geographical allocation of risks and hold proportionally less capital than small firms. Due to economies of scale in risk management and the greater ability of large firms to raise capital in the short run, large firms are expected to require less capital to operate and can take on larger risk (Titman and Wessels, 1988; Aggarwal and Jacques, 2001).

Numerous studies indicate that firm size negatively affects the demand for reinsurance (Hoerger et al., 1990; Adams, 1996 and Powell and Sommer, 2007). Small insurers depend more on reinsurance use because they do not have economies of scale and scope, and they have higher financing costs when raising external funds for at least two main reasons (Adams, 1996). First, the direct costs of financial failure are not proportional to the size of a company (Warner, 1977). Second, raising capital in financial markets is an expensive undertaking. Cole and McCullough (2006) view size as an inverse measure of bankruptcy costs and find a negative relationship between this variable and the demand for reinsurance. Thus, large insurers will be less dependent on reinsurance for expansions of their underwriting capacity. We formulate the following hypothesis:

\section{$\mathrm{H}_{4}$ : Large firms hold less capital and reinsurance than small firms. The inverse effect is observed with risk}

\section{Organizational form}

There are two main forms of organization in the insurance industry: stock firms, which are owned by shareholders, and mutual firms, which are owned by policyholders. The managerial discretion hypothesis suggests that stock insurers tend to undertake relatively more complex and risky projects (Mayers and Smith, 1990). However, shareholders have more control over managers in such firms than in other organization forms. The implications of pecking order theory will vary, depending on organizational form. Stock firms have greater access to the financial markets. Mutual firms have more difficulties in raising capital than stock insurers. In addition, agency costs vary depending on a firm's organizational form. Conflicts between shareholder and policyholders may impact the choice of capital level. Harrington and Niehaus (2002) find that mutual insurers tend to hold more capital than stock insurers. Cummins et al. (2001) predict that managers of mutual firms are more risk averse because of their specific organization and other difficulties in diversifying their wealth. Thus, such firms are more likely to manage risk through reinsurance. Indeed, Cole and McCullough (2006) note that mutual firms, which have less access to capital markets in cases of catastrophic loss, use more reinsurance. Thus, we formulate the following hypothesis:

\section{$\mathrm{H}_{5}$ : There is a negative (positive) relationship between stock firms and reinsurance or capital (risk-taking).}

\section{Affiliated vs nonaffiliated insurers}

An extensive literature has focused on capital transfer within financial groups (Stein, 1997; Campello, 2002). Affiliated insurers generally hold less capital and have incentives to take more risk, as they have access to internal resources provided by other affiliates. It is also easier for them to obtain capital injections from parent firms when their capital levels become insufficient. Powell et al. (2008) investigate whether or not internal capital markets are active within insurance groups. 
They find evidence that they play a significant role in the investment behavior of affiliated insurers, and that capital is allocated to subsidiaries with the best expected performance.

Like capital and risk, reinsurance transactions can also be grouped into reinsurance with affiliates and reinsurance with nonaffiliated. According to Mayers and Smith (1990) and Powell and Sommer (2007), this decision can be regarded as an internal capital market transaction. Reinsurance can transfer income within the group and reduce the overall tax burden (Mayers and Smith, 1990). In addition, it allows affiliated insurers to take advantage of risk diversification through intra-group reinsurance (Cole and McCullough, 2006). This is confirmed by Powell and Sommer (2007), who argue that transactions into group have lower asymmetric information costs than those with nonaffiliates and thus it implies lower monitoring costs. Accordingly, we posit the following hypothesis:

\section{Control variables}

The empirical literature identifies several factors that may affect the endogenous variables. Here, we present the most important factors in the empirical model developed below.

\subsection{Determinants of Capital}

\section{Performance}

Firms with high profitability generally have sufficient internal funds that may be transformed into capital. According to pecking order theory, firms prefer internal to external financing (i.e., debt or new equity) due to the costs of issuing new equity or debt. Alternatively, in the presence of asymmetric information, the use of external funding may convey negative information to the market about the firm's value. If the behavior of insurers is consistent with pecking order theory, we expect performance to positively affect capital levels. Following Titman and Wessels (1988) and Fama and French (2002), we use return on assets as an indicator of profitability.

\section{Cost of capital}

The cost of holding capital is an important determinant of capital levels (Estrella, 2004). Various costs, such as agency and information asymmetry costs, are related to the use of capital, and the level of capital is expected to be inversely related to such costs. The cost of holding capital is difficult to measure in practice. Similarly to (Ayuso et al., 2004 and Jokipii and Milne, 2008), we approximate this cost as the average of positive returns on equity (ROE) over the last five years.

\section{Information asymmetry}

Signal theory suggests that information asymmetry and the opacity of the insurance industry are important determinants of capital levels (Pottier and Sommer, 2006 and Morgan, 2002). Insurers with volatile incomes are likely to use retained earnings rather than external capital to address future losses or cope with shocks. Insurers can overcome information asymmetry by building a capital stock in periods of high profitability. We use the volatility of ROE as a measure of information asymmetry (Cummins and Nini, 2002 and Grubisic and Leadbetter, 2007).

\section{Exposure to extreme risk}

Exposure to extreme risks is also likely to influence the level of capital. Zanjani (2002) illustrates that companies that insure heavily against natural disasters have higher capital levels than those that are less exposed to such events. The level of exposure to extreme risk is measured in our model as a percentage of total premiums written in the earthquake line of business (Cummins and Song, 2008).

\section{Liquidity risk}

Insurers with a large share of liquid assets are more likely than others to face regulatory constraints. The low risk associated with these assets allows for easy adjustments to capital levels. 
Therefore, insurers with more liquid assets are expected to have less capital and take greater risk. De Ceuster (2003) finds that the major source of illiquidity is asset-liability mismatch, which may encourage insurance firms to hold more capital. In this study, liquidity risk is measured by the ratio of liabilities to liquid assets.

\section{Cost inefficiency}

Hughes and Moon (1995) emphasize the importance of analyzing the impact of inefficiency on capital, establishing a negative relationship between these two variables. For instance, Altunbas et al. (2007) note that the cost inefficiency of European banks is due to their high capital levels and moderate risk-taking. This factor is generally estimated using non-parametric methods. However, some studies argue that financial ratios are very simple estimates of cost inefficiency. For simplicity, this variable is measured in this study as the ratio of operating expenses to net income.

\section{Deficit}

Deficits reflect the need for external financing when internal cash flows are exhausted. This variable is used to test for the existence of a preference ordering among funding sources for insurers. According to pecking order theory, this factor, which is measured hereafter by the level of investment plus changes in working capital minus internal cash flow, has a positive impact on the level of capital (De Bie and De Haan, 2007).

\section{Growth opportunities}

Insurers with better growth opportunities are expected to hold more capital. The literature uses the book-to-market ratio or changes in $\mathrm{R} \& \mathrm{D}$ expenses to measure this variable. ${ }^{2}$ However, due to a lack of data, we use an alternative measure, as in Carayannopoulos and Kelly (2005), namely, the past growth (over five years) in premiums.

\subsection{Determinants of risk-taking}

Existing theoretical and empirical work suggests that risk-taking will be affected by various factors, including the following.

\section{Leverage}

Empirical work in the insurance industry (e.g., Borde et al., 1994) confirms the relevance of firm leverage and argues that risk-taking can be influenced by this factor, which tends to amplify returns and/or losses. A high debt ratio worsens the underinvestment problem, the risk of insolvency, and bankruptcy costs. Thus, we expect a negative relationship between risk-taking and leverage. Therefore, we expect a negative relationship between risk taking and leverage. In the empirical model below, this variable is approximated by the ratio of liabilities to surplus.

\section{Cost inefficiency}

Cost inefficiency can also have an effect on risk-taking. For the banking sector, Berger and DeYoung (1997) and Williams (2004) introduce the "bad management" hypothesis and demonstrate that a decline in costs or revenue efficiency temporally precede increases in risktaking. Thus, we expect a positive relationship between inefficiency and risk-taking.

\section{Business mix}

The business mix is the degree of centering on a firm's core business. Previous research has found that differences in risk across a firm's various lines of business positively affect reinsurance levels. Thus, we expect a positive relationship between the degree of centering and risk-taking.

${ }^{2}$ Hovakimian et al. (2001) and Fama and French (2002) use the book to market ratio as a proxy for a firm's growth opportunities (GROWTH). This proxy is defined as the ratio of the book value of total assets minus the book value of equity and debt plus the ratio of market value of equity and debt to the book value of total assets (Barclay and Smith, 1995; Rajan and Zingales, 1995). 
This variable is approximated by the Herfindahl index of the four major branches of non-life insurance business, namely, short- and long-term personal insurance and short-term and long-term commercial insurance.

\section{Geographic and line of business diversification}

An insurer may reduce its overall risk by holding a portfolio whose components are not perfectly correlated across regions and/or activities. Empirical studies find that in the banking sector, diversification is associated with moderate risk-taking (Hughes, Lang and Mester, 1996 and Deng et al., 2007), a hypothesis based on the benefits of cost reduction and income synergy (Saunders and Cornett, 2007). Alternatively, diversification may be associated with higher risktaking because of the agency problem and competition. The degree of diversification is measured by the Herfindahl index percentages of direct premiums written by line of business and geographical area.

\subsection{Determinants of reinsurance}

Researchers have documented that reinsurance can be affected by several firm-specific factors.

\section{Performance}

Adams et al. (2008) predict that the poorest-performing insurance companies tend to use more reinsurance than profitable companies, which have more resources to cope with financial risk and thus lower probabilities of bankruptcy. This performance is measured by the return-on-assets ratio.

\section{Loss volatility}

Reinsurance is generally used to stabilize underwriting profits. When the loss ratio is highly volatile, the insurer has less certainty of future value losses and thus greater incentive to use reinsurance. According to Hoerger et al., (1990), an increased volatility of claims gives rise to increased reinsurance demand. This factor is approximated by the standard deviation of the loss ratio over the last three years.

\section{Liquidity risk}

Lee and Urrutia (1996) find that the liquidity ratio is an important indicator of solvability. An insurer with relatively liquid assets has more stable finances and is thus expected to use less reinsurance. Conversely, insurance companies with insufficient liquidity are likely to use more reinsurance (Plantin, 2006).

\section{Reinsurance price}

Cole and McCullough (2006) explore the impact of reinsurance prices on reinsurance demand, finding a negative correlation between the costs of the use of reinsurance and demand for this risk management tool. This price is approximated by the ratio of premiums ceded minus losses to claims recovered from reinsurers.

\section{Inefficiency}

The impact of inefficiency on reinsurance adjustment is similar to that of performance in the sense that less efficient insurers tend to use more reinsurance than other firms. The relationship between inefficiency and the level of reinsurance is expected to be negative.

\section{Business Mix}

Mayers and Smith (1990) examine the effects of the composition of a firm's portfolio of activities on the demand for reinsurance. They observe that an increased concentration of activities increases the volatility of cash flows and the risk of bankruptcy. Reinsurance could be a solution to the risk of insolvency arising from this source. Moreover, Shortridge et al. (2004) and Cole et al. (2006) demonstrate that this factor reflects the degree of centering on the core business. In 
contrast, the economic benefits of specialization can reduce the demand for reinsurance. We predict a negative relationship between the degree of specialization and the demand for reinsurance.

\section{Line-of-Business and geographic concentration}

A high concentration of premiums in certain lines of business exposes insurers to significant risk. However, high concentration may also reflect specialization and better risk pricing. Thus, the effect of concentration on the demand for reinsurance is not clearly defined. In contrast, geographical concentration reflects the degree of diversification of an insurer across states. Cole and McCullough (2006) find a negative relationship between geographic concentration and reinsurance and between lines-of-business concentration and reinsurance. Garven and LammTenant (2003) and Mayers and Smith (1990) also find a negative relationship using a different measure of diversification. These variables are measured by the Herfindahl index of the percentage of direct premiums written by lines of business and geographic area, respectively.

\section{Methodology}

\subsection{Model}

In this section, we investigate the short-run relationships between capital, reinsurance, and risk using simultaneous equations. Importantly, the observed variations of these variables are both discretionary and caused by factors exogenous to the insurer (Shrieves and Dahl, 1992; Jacques and Nigro 1997; Cummins and Sommer, 1996; Baranoff et al., 2007; Shim, 2010). To account for this behavior, we introduce lagged variables as partial adjustment components ( $f$. appendix 1). The model has the following specification:

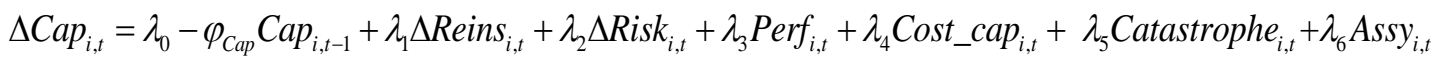

$$
\begin{aligned}
& +\lambda_{7} \text { Lqt_risk }_{i, t}+\lambda_{8} \text { Cost_ineff }_{i, t}+\lambda_{9} \text { Growth }_{i, t}+\lambda_{10} \text { Deficit }_{i, t}+\lambda_{11} \text { Org }_{i, t}+\lambda_{12} \text { Group }_{i, t}+\lambda_{13} \text { Size }_{i, t}+\text { Year }_{t}+e_{i, t} \\
& \Delta \text { Reins }_{i, t}=\beta_{0}-\varphi_{\text {Reins }} \text { Reins }_{i, t-1}+\beta_{1} \Delta \text { Cap }_{i, t}+\beta_{2} \Delta \text { Risk }_{i, t}+\beta_{3} \text { Loss_vol }_{i, t}+\beta_{4} \text { Perf }_{i, t}+\beta_{5} \text { Lqt_risk }_{i, t}+\beta_{6} \text { Reins_price }_{i, t} \\
& +\beta_{7} \text { Mix }_{i, t}+\beta_{8} \text { Hibl }_{i, t}+\beta_{9} \text { Higeo }_{i, t}+\beta_{10} \text { Cost_ineff }_{i, t}+\beta_{11} \operatorname{Org}_{i, t}+\beta_{12} \text { Group }_{i, t}+\beta_{13} \text { Size }_{i, t}+\text { year }_{t}+u_{i, t} \\
& \Delta \text { Risk }_{i, t}=\gamma_{0}-\varphi_{\text {Risk }} \text { Risk }_{i, t-1}+\gamma_{1} \Delta \operatorname{Re}_{i n n_{i, t}}+\gamma_{2} \Delta \text { Cap }_{i, t}+\gamma_{3} \text { Lev }_{i, t}+\gamma_{4} \text { Mix }_{i, t}+\gamma_{5} \text { Hibl }_{i, t}+\gamma_{6} \text { Higeo }_{i, t} \\
& +\gamma_{7} \text { Cost_ineff }_{i, t}+\gamma_{8} \operatorname{Org}_{i, t}+\gamma_{9} \text { Group }_{i, t}+\gamma_{10} \text { Size }_{i, t}+\text { year }_{t}+v_{i, t}
\end{aligned}
$$

where $e_{i, t}, v_{i, t}$, and $\boldsymbol{u}_{i, t}$ are error terms.

Cap, Reins, and Risk denote the capital ratio, reinsurance ratio, and risk level, respectively. The definitions and descriptions of various control variables are reported in Table 1. Time effects are included in the model to consider systematic events and high losses associated with man-made and natural disasters.

\subsection{Variables construction}

\section{Capital (Cap):}

As most of the insurers in our sample are not listed, it is not possible to determine their market values. Similar to Aggarwal and Jacques (2001), Cummins and Sommer (1996), and Shim (2010), we proxy the capital ratio by the book value of the surplus divided by the total value of assets.

\section{Reinsurance (Reins):}

This variable is given, for each insurer, by the ratio of total reinsurance premiums ceded to total business premiums (Garven and Lamm-Tennant, 2003; Cole and McCullough, 2006; and Powell and Sommer, 2007).

\section{Risk (Risk):}


Based on portfolio theory, we measure total risk by the volatility of the asset-to-liability ratio. According to Cummins and Sommer (1996) and Shim (2010), an insurer's asset volatility can be expressed as follows:

$$
\sigma=\sqrt{\sigma_{A}^{2}+\sigma_{L}^{2}-2 \sigma_{A . L}}
$$

where $\sigma_{A}$ and $\sigma_{L}$ are the volatility measures of the insurer's assets and liabilities, respectively, and $\sigma_{A, L}$ is the covariance of the logarithms of the assets and liability values. Let us denote the proportion of assets of asset type ( $i$ in the investment portfolio by $x_{i}$ and the proportion of liabilities from business line ( $)$ by $y_{j}$. The respective volatilities of the asset and liability portfolios and the covariance of the logarithms of the liability and asset returns are given as follows:

$$
\begin{gathered}
\sigma_{A}^{2}=\sum_{i=1}^{N} \sum_{j=1}^{N} x_{i} x_{j} \rho_{A_{i} A_{j}} \sigma_{A_{i}} \sigma_{A_{j}} \\
\sigma_{L}^{2}=\sum_{i=1}^{M} \sum_{j=1}^{M} y_{i} y_{j} \rho_{L_{i} L_{j}} \sigma_{L_{i}} \sigma_{L_{j}} \\
\sigma_{A L}=\sum_{i=1}^{N} \sum_{j=1}^{M} x_{i} y_{j} \rho_{A_{i} L_{j}} \sigma_{A_{i}} \sigma_{L_{j}}
\end{gathered}
$$

$\sigma_{A_{i}}$ and $\sigma_{L_{j}}$ denote the volatilities of the log of asset type (i) and the log of liabilities in business line (j), respectively. The parameter $\rho_{A_{i} L_{j}}$ reflects the correlation between the log of the $i^{\text {th }}$ asset and the log of the liabilities in the $j^{\text {th }}$ business line, whereas $N$ is the number of asset categories and $M$ is the number of lines of business. To measure risk using this measure of volatility, one must first define different lines of activities and asset categories. Following Shim (2010), we aggregate each insurer's lines of business into 12 categories: homeowners/farm-owners, auto physical damage, auto liability, commercial multiple peril, special property, fidelity/surety, accident, health, and financial guaranty, medical malpractice, workers' compensation, other liability, special liability, and miscellaneous liability. The types of assets are classified into seven categories: stocks, government bonds, corporate bonds, real estate, mortgages, cash and other invested assets, and non-invested assets. A second risk measure used to assess the robustness of our results is the RBC ratio, introduced by the National Association of Insurance Commissioners (NAIC). This measure offers an alternative way of accounting for the risk of insurers (Chang and Weiss, 2012 ${ }^{\mathrm{b}}$ ). More specifically, it reflects the minimal capital level required of insurers. All else equal, an insurer's capital requirement must be higher as more risk is taken on.

\subsection{Estimation methodology}

In capturing interactions between capital, risk, and reinsurance, simultaneous equation models have shown better performance than estimating the equations individually, as the latter approach ignores the problem of endogeneity and may violate the condition of no correlation between exogenous variables and error terms (Baltagi, 2005). To address this problem in the relationship between the key variables and to avoid biased OLS estimates, we employed the three-stage leastsquares (3SLS) technique (Shim, 2010; Rime, 2001; Jacques and Nigro, 1997 and Aggarwal and Jacques, 1998). We used instrumental variables, checking their validity using the Sargan Hansen test. In the first step, we estimate the model using the OLS and 3SLS methods, comparing the results using the Durbin-Wu Hausman test. As we find significant differences in the estimates, the endogeneity problem is confirmed. Regarding the choice of instruments, we use the risk and reinsurance variables (lagged two periods), the economic growth rate, and the ratio of unrealized gains (with no lag and lagged one period). All of the other predetermined variables are used as 
instruments in the structural estimation. Prior to estimation, we attempt to verify whether the time series are stationary based on the Levin-Lin-Chu test.

Table 1. Variable definitions

\begin{tabular}{|c|c|c|c|c|}
\hline \multirow{2}{*}{ Variable } & \multirow{2}{*}{ Measure } & \multicolumn{3}{|c|}{ Expected sign } \\
\hline & & $\Delta$ Cap & $\Delta R e i n s$ & $\Delta R$ Risk \\
\hline \multicolumn{5}{|c|}{ Endogenous variables } \\
\hline Cap & Ratio of surplus to total admitted assets & . & $(+/-)$ & $(+/-)$ \\
\hline \multirow{2}{*}{ Reins } & Ratio of reinsurance premiums ceded to direct business & & & \\
\hline & written plus reinsurance assumed & $(-)$ & . & $(+)$ \\
\hline Risk1 & Volatility of the asset to liability ratio & $(+)$ & $(+)$ & . \\
\hline Risk:2 & Ratio of RBC to total admitted assets & $(+)$ & $(+)$ & . \\
\hline \multicolumn{5}{|c|}{ Exogenous variables } \\
\hline \multirow{2}{*}{$\operatorname{Reg}$} & 1 if firm's net premium to surplus ratio $=$ or $>300 \%, 0$ & . & . & . \\
\hline & Otherwise & & & \\
\hline Perf & Return on assets ratio & $(+)$ & $(-)$ & . \\
\hline Cost_cap & Average of positive ROE over the last five years & $(-)$ & . & . \\
\hline Catastrophe & $\begin{array}{l}\text { Proportion of direct premiums written in earthquake line of } \\
\text { business }\end{array}$ & $(+)$ & . & . \\
\hline Roe_vol & $\begin{array}{l}\text { The standard deviation of the firm's ROE over the last five } \\
\text { years }\end{array}$ & $(+)$ & . & . \\
\hline Cost_ineff & Ratio of total expenses to net earnings & $(+)$ & $(+)$ & $(+)$ \\
\hline Reinsprice & $\begin{array}{l}\text { Ratio of reinsurance premiums minus ceded-reinsurance } \\
\text { commission earned to claims recovered from reinsurers }\end{array}$ & · & $(-)$ & · \\
\hline Mix & $\begin{array}{l}\text { Herfindahl index of short and long tails of personal and } \\
\text { commercial lines }\end{array}$ & & $(-)$ & $(+)$ \\
\hline Lqt_risk & Ratio of liabilities to liquid assets & $(+)$ & $(+)$ & . \\
\hline Loss_vol & Standard deviation of the loss ratio over the last three years & . & $(+)$ & . \\
\hline Lev & Ratio of direct business written to surplus & & & $(-)$ \\
\hline Hibl & $\begin{array}{l}\text { Herfindahl index of direct premium written across all lines of } \\
\text { business }\end{array}$ & . & $(+)$ & $(+/-)$ \\
\hline Higeo & $\begin{array}{l}\text { Herfindahl index of direct premium written across geographic } \\
\text { areas }\end{array}$ & . & $(+)$ & $(+/-)$ \\
\hline Growth & Percentage growth of written premiums & $(+/-)$ & . & . \\
\hline Deficit & $\begin{array}{l}\text { Financial deficit ratio calculated as cash dividends plus } \\
\text { investments plus change in working capital minus internal cash } \\
\text { flow. }\end{array}$ & $(+/-)$ & $\cdot$ & · \\
\hline Stock & 1 if the insurer is a stock firm, 0 if it is a mutual firm & $(-)$ & . & . \\
\hline Group & 1 if the insurer is a member of a group in year $t, 0$ otherwise & $(-)$ & . & . \\
\hline Size & The logarithm of total admitted assets & $(-)$ & . & . \\
\hline Year & Annual temporal effect & . & . & . \\
\hline
\end{tabular}

This table describes the variables used in the empirical model. 


\section{Data}

\subsection{Sample}

The data used in this study are collected from the National Association of Insurance Commissioners (NAIC) annual statement database for U.S. property-liability insurers from 1999 to 2008. The sample is limited to solvent insurers reporting positive values of admitted assets, gross and net premiums written, equity capital, and ceded reinsurance premiums. We retain only active insurers with no regulatory actions in process. After applying these sample screens, our final sample consists of 11,929 year-firm observations. It accounts for $81 \%(84 \%)$ of the entire U.S. property-liability market in terms of total assets in the year 1999 (2008). We use an unbalanced data panel to allow for a comprehensive evaluation of the property-liability market. The sample includes firms that entered or left the market during the study period. In addition to the NAIC database, we also collected data from DataStream to estimate asset returns. ${ }^{3}$

\subsection{Descriptive statistics and correlation analysis}

Table 2 presents descriptive statistics of all variables used in this study. The mean and median of the capital ratio are approximately $38 \%$ and $42 \%$, respectively. These statistics are $(39 \%, 34 \%)$ and $(0.026,0.004)$, respectively, for the reinsurance ratio and risk level. These values exceed those reported in Garven and Lamm-Tennant (2003), suggesting a significant increase in reinsurance demand over the last decade. The distributions of the two risk measures are positively skewed. With regard to the diversification profiles measured by the two Herfindahl indices (Higeo and $\mathrm{Hibl}$ ), we note small variations across insurers. Approximately $73 \%$ of insurers are stock firms, and $70 \%$ are affiliated. Before conducting the regression analysis, we first considered the possibility of multi-collinearity among independent variables, which may lead to biased estimates. Table 3 reports the Pearson correlation between the variables included in the regression model. Table 3 indicates that the correlation between capital and risk is positive, confirming the hypothesis that insurers adjust their capital levels upward following increases in risk. The relation between risk and reinsurance is negative, which is in line with the view of reinsurance as a guarantee fund. Another interesting result reported in Table 3 is the low correlation between the two risk measures. ${ }^{4}$ The Spearman nonparametric correlation between these two risk measures (not reported here) is statistically significant at the $1 \%$ level and is equal to 0.1 . Interestingly, cost inefficiency correlates significantly with all key variables. Consistent with standard econometric practice, for each equation, we assess the degree of multi-collinearity among the independent variables using the variance inflation factor (VIF). All VIF values reported in Table 4 range between 1.01 and 2.2. Thus, no multi-collinearity was observed among the independent variables.

\footnotetext{
${ }^{3}$ We use the S\&P 500 global index, Barclays capital, US 20 year Treasury bond, Dow Jones Corporate bond index, Merrill Lynch Mortgage, U.S. real estate \& rental \& leasing and the three-month U.S. treasury bill as proxies for asset returns.

${ }_{4}^{4}$ Many criticisms have been addressed regarding RBC as an insolvency predictor (e.g., Cummins, Grace and Phillips, 1999; Cummins, Harrington and Klein, 1995). Cheng and Weiss (2012) find that the accuracy of the RBC ratio in predicting insolvencies is inconsistent over time.
} 
Table 2. Descriptive statistics

\begin{tabular}{|c|c|c|c|c|c|c|c|c|}
\hline & Mean & Median & Std dev. & Min & Max & $\begin{array}{c}5 \% \\
\text { quantile }\end{array}$ & $\begin{array}{c}95 \% \\
\text { quantile }\end{array}$ & $\begin{array}{c}\text { No. of } \\
\text { obs. }\end{array}$ \\
\hline Cap & 0.417 & 0.380 & 0.166 & 0.092 & 1.000 & 0.153 & 0.912 & 11929 \\
\hline Reins & 0.389 & 0.340 & 0.277 & 0.000 & 2.679 & 0.000 & 0.948 & 11929 \\
\hline Risk1 & 0.026 & 0.004 & 0.181 & 0.000 & 2.839 & 0.000 & 0.346 & 11929 \\
\hline Risk:2 & 0.139 & 0.099 & 0.356 & 0.001 & 8.817 & 0.006 & 0.790 & 11929 \\
\hline Perf & 0.025 & 0.027 & 0.049 & -0.603 & 0.667 & -0.117 & 0.151 & 11929 \\
\hline Loss_vol & 1.325 & 0.741 & 4.472 & 0.043 & 171.054 & 0.141 & 8.720 & 11929 \\
\hline Assy & 0.077 & 0.048 & 0.100 & 0.000 & 2.034 & 0.004 & 0.450 & 11929 \\
\hline Cost_cap & 0.058 & 0.062 & 0.108 & -0.996 & 1.783 & -0.308 & 0.316 & 11929 \\
\hline Lat_risk & 0.748 & 0.733 & 0.518 & 0.000 & 19.446 & 0.092 & 1.938 & 11929 \\
\hline Growth & 0.124 & 0.050 & 0.633 & -8.470 & 9.989 & -0.857 & 2.653 & 9578 \\
\hline Deficit & 0.059 & 0.058 & 0.153 & -1.467 & 0.842 & -0.413 & 0.502 & 11929 \\
\hline Cost_ineff & 0.115 & 0.098 & 0.111 & -0.908 & 6.110 & 0.000 & 0.447 & 11929 \\
\hline Higeo & 0.388 & 0.376 & 0.095 & 0.250 & 0.773 & 0.260 & 0.500 & 11929 \\
\hline Hibl & 0.368 & 0.351 & 0.067 & 0.272 & 0.753 & 0.281 & 0.500 & 11929 \\
\hline Mix & 0.333 & 0.281 & 0.320 & 0.000 & 1.000 & 0.000 & 1.000 & 11929 \\
\hline Reins_price & 0.527 & 8.775 & 3.103 & 7.091 & 4.817 & 4.296 & 5.595 & 11929 \\
\hline Lev & 1.735 & 1.293 & 1.609 & 0.000 & 9.928 & 0.008 & 8.003 & 11929 \\
\hline Size & 18.546 & 18.456 & 1.812 & 12.845 & 24.384 & 14.887 & 23.279 & 11929 \\
\hline Stock & 0.735 & 1.000 & 0.442 & 0.000 & 1.000 & 0.000 & 1.000 & 11929 \\
\hline Group & 0.692 & 1.000 & 0.462 & 0.000 & 1.000 & 0.000 & 1.000 & 11929 \\
\hline Cycle & 0.017 & 0.019 & 0.021 & -0.035 & 0.042 & -0.035 & 0.042 & 11929 \\
\hline$U_{c g}$ & -0.036 & 0.000 & 1.287 & -99.872 & 8.104 & -0.210 & 0.070 & 11929 \\
\hline Dev_ni & 0.047 & -0.111 & 0.893 & -2.816 & 2.846 & -2.189 & 2.737 & 9578 \\
\hline
\end{tabular}

This table reports the mean, median, minimum, maximum, standard deviation, fifth percentile, and 95th percentile of all variables. The data are collected from the NAIC and Datastream databases covering U.S. property-liability insurance firms from 1999 to 2008. 
Table 3. Correlation coefficient matrix

\begin{tabular}{|c|c|c|c|c|c|c|c|c|c|c|c|c|c|c|c|c|c|c|c|}
\hline & & (a) & (b) & (c) & (d) & (e) & (f) & (g) & (h) & (i) & (j) & (k) & (l) & $(\mathrm{m})$ & (n) & (o) & (p) & (q) & (r) \\
\hline Cap & (a) & 1 & & & & & & & & & & & & & & & & & \\
\hline Reins & (b) & -0.007 & 1 & & & & & & & & & & & & & & & & \\
\hline Risk1 & (c) & $0.041^{*}$ & $-0.043^{*}$ & 1 & & & & & & & & & & & & & & & \\
\hline Risk2 & (d) & 0.009 & -0.007 & 0.009 & 1 & & & & & & & & & & & & & & \\
\hline Perf & (e) & $0.213^{*}$ & $-0.058^{*}$ & 0.014 & -0.009 & 1 & & & & & & & & & & & & & \\
\hline Loss_vol & (f) & $0.068^{*}$ & $0.076^{*}$ & 0.008 & 0.009 & $-0.068^{*}$ & 1 & & & & & & & & & & & & \\
\hline Assy & (g) & $-0.233^{*}$ & $0.025^{*}$ & $-0.027^{*}$ & $0.032^{*}$ & $-0.167^{*}$ & $0.102^{*}$ & 1 & & & & & & & & & & & \\
\hline Cost_cap & (h) & $0.093^{*}$ & $-0.082^{*}$ & 0.021 & $-0.026^{*}$ & 0.640 & $-0.098^{*}$ & $-0.378^{*}$ & 1 & & & & & & & & & & \\
\hline Lqt_risk & (i) & $-0.492^{*}$ & $0.162^{*}$ & -0.023 & -0.007 & $-0.137^{*}$ & -0.015 & $0.135^{*}$ & $-0.081^{*}$ & 1 & & & & & & & & & \\
\hline Growth & (j) & $-0.025^{*}$ & $-0.047^{*}$ & -0.006 & 0.003 & -0.082 & $0.112^{*}$ & -0.018 & $-0.032^{*}$ & $0.049^{*}$ & 1 & & & & & & & & \\
\hline Deficit & $(\mathrm{k})$ & $-0.139^{*}$ & $-0.044^{*}$ & 0.020 & 0.003 & 0.018 & 0.011 & $-0.044^{*}$ & $0.041^{*}$ & $0.126^{*}$ & $0.388^{*}$ & 1 & & & & & & & \\
\hline Cost_ineff & (l) & $-0.075^{*}$ & $0.116^{*}$ & $-0.030^{*}$ & 0.001 & $-0.163^{*}$ & $0.050^{*}$ & $0.123^{*}$ & $-0.175^{*}$ & 0.013 & $-0.133^{*}$ & $-0.250^{*}$ & 1 & & & & & & \\
\hline Higeo & (m) & $0.155^{*}$ & $-0.192^{*}$ & $-0.053^{*}$ & $0.029^{*}$ & 0.001 & 0.007 & $0.047^{*}$ & -0.052 & $-0.071^{*}$ & -0.007 & 0.011 & $0.049^{*}$ & 1 & & & & & \\
\hline Hibl & (n) & $0.103^{*}$ & $-0.132^{*}$ & 0.088 & 0.014 & $0.040^{*}$ & $0.060^{*}$ & $0.045^{*}$ & $0.008^{*}$ & -0.009 & $0.037^{*}$ & $0.048^{*}$ & $0.074^{*}$ & 0.204 & 1 & & & & \\
\hline Mix & (o) & $0.081^{*}$ & $0.040^{*}$ & $-0.066^{*}$ & 0.018 & $-0.032^{*}$ & -0.007 & -0.012 & $-0.056^{*}$ & $-0.098^{*}$ & -0.004 & -0.004 & 0.009 & $0.054^{*}$ & $-0.189^{*}$ & 1 & & & \\
\hline Reins_price & (p) & $0.041^{*}$ & $-0.052^{*}$ & 0.013 & -0.007 & 0.050 & 0.017 & 0.004 & $0.045^{*}$ & $-0.038^{*}$ & $0.033^{*}$ & $0.055^{*}$ & $-0.027^{*}$ & $0.037^{*}$ & $0.134^{*}$ & -0.008 & 1 & & \\
\hline Lev & (q) & $-0.390^{*}$ & $0.470^{*}$ & $-0.047^{*}$ & 0.016 & $-0.113^{*}$ & -0.022 & $0.187^{*}$ & $-0.116^{*}$ & $0.395^{*}$ & $0.061^{*}$ & $0.121^{*}$ & -0.003 & 0.001 & $-0.116^{*}$ & $-0.106^{*}$ & $-0.057^{*}$ & 1 & \\
\hline Size & (r) & $-0.368^{*}$ & $-0.037^{*}$ & 0.002 & $-0.070^{*}$ & 0.059 & $-0.035^{*}$ & $-0.036^{*}$ & $0.156^{*}$ & $0.153^{*}$ & $-0.025^{*}$ & 0.023 & $-0.032^{*}$ & $-0.478^{*}$ & $-0.221^{*}$ & $-0.076^{*}$ & $-0.030^{*}$ & $-0.115^{*}$ & 1 \\
\hline
\end{tabular}

* represents statistical significance at $1 \%$ level.

Table 4. V ariance inflation factors

\begin{tabular}{|c|c|c|c|c|c|}
\hline \multicolumn{2}{|c|}{ Eq $\triangle$ Cap } & \multicolumn{2}{|c|}{ Eq AReins } & \multicolumn{2}{|c|}{ Eq $\Delta$ Risk } \\
\hline$\Delta$ Risk & 1.02 & Arisk1 & 1.02 & $\triangle$ Cap & 1.11 \\
\hline $\operatorname{Cap}(t-1)$ & 1.67 & $\triangle$ Cap & 1.24 & $\Delta$ Reins & 1.04 \\
\hline$\Delta$ Reins & 1.12 & $\operatorname{Reins}(t-1)$ & 1.18 & Riske(t-1) & 1.03 \\
\hline Cost_cap & 2.2 & Cost_ineff & 1.1 & Lev & 1.1 \\
\hline Perf & 1.97 & Loss_vol & 1.03 & Cost_ineff & 1.06 \\
\hline Assy & 1.26 & Reins_price & 1.03 & Hibl & 1.18 \\
\hline Deficit & 1.36 & Perf & 1.27 & Higeo & 1.41 \\
\hline Growth & 1.36 & I Iibl & 1.18 & Size & 1.49 \\
\hline Cost_ineff & 1.14 & Mix & 1.12 & Mix & 1.14 \\
\hline Lqt_risk & 1.38 & Higeo & 1.44 & Group & 1.24 \\
\hline Catastrophe & 1.01 & Sire & 1.51 & Stock & 1.18 \\
\hline Size & 1.39 & Group & 1.28 & & \\
\hline Stack & 1.09 & Stock & 1.21 & & \\
\hline Group & 1.22 & & & & \\
\hline Mean VIF & 1.37 & Mean VIF & 1.2 & Mean VIF & 1.18 \\
\hline
\end{tabular}

For definitions of these variables, see Table 1. 


\section{Results}

This section discusses the empirical results. The system of equations is estimated under two specifications, which alternatively exclude and include the regulatory pressure mechanisms. We estimate the model for the full sample and for various subgroups, reflecting the level of capital, size, and organizational form of firms. Finally, we perform several robustness tests.

\subsection{Full sample}

\section{Equation of capital}

The main hypothesis tested in this paper concerns the existence of interconnections between risk-taking, capital, and reinsurance. Table 5 reports the 3SLS estimation of the simultaneous equations using volatility as a risk measure. The Hansen and Sargan test shows the validity of the selected instrumental variables used in the first step of the estimation process. A closer look at the individual equations' coefficients indicates that most key variable estimations are in line with expectations.

The first column of Table 5 reports the results for the capital equation. Overall, the coefficients are significant, except for that on exposure to extreme risks. The risk variable is positive and statistically significant, a result that is consistent with the capital buffer hypothesis, suggesting that an increase in portfolio risk leads to positive adjustments of capitalinsurers as a guaranty against unanticipated extreme losses (Jokipii and Milne, 2011).

Second, the negative sign of the Reins adjustment variable supports the original hypothesis regarding the substitutability between these two variables. This result is consistent with the findings of Stulz (1996) and Armstrong and Dror (2006), who argue that reinsurance can serve as offbalance sheet capital that reduces capital requirements and allows the insurer to expand its capacity to issue new policies.

Concerning the main control variables, the table shows that the partial adjustment factor, a measure of convergence toward the desired long-run capital ratio, which is captured by the lagged endogenous variable, is low (0.0519). This result can be explained by the presence of various adjustment costs. ${ }^{5}$ Performance appears to have a significant and positive effect on capital, confirming pecking order theory and suggesting that profitable firms prefer internal financing and rely heavily on retained earnings to raise capital because of the costs of external funds. The cost of capital variable is negative and significant, which highlights the important costs related to the use of capital. Moreover, an increase in information asymmetry, measured by the volatility of ROE, drives insurers to hold more capital. This variable reflects the level of risk to some extent and thereby confirms the positive relationship between these two variables. Economic inefficiency is positively related to capital adjustment. The coefficient on this variable is significantly and negatively associated with liquidity. We also note the presence of significant temporal effects, which may be explained by the impact of various macroeconomic shocks or extreme losses of capital.

The introduction of regulatory pressure mechanisms in the second specification (first column of the right-hand side of the table) slightly alters the estimation results. For the most part, the coefficients of the new variables are statistically significant. The estimates of the capital equation provide support for the hypothesis that undercapitalized insurers bearing more risk seek to avoid regulatory intervention. Only the coefficient on $\operatorname{Reg}_{t-1} \times \operatorname{Reins}_{t-1}$ is positive and statistically significant. These results indicate that highly leveraged companies in the previous period tend to increase their levels of reinsurance to adjust their capital levels to avoid regulatory costs.

\footnotetext{
${ }^{5}$ We do not examine the possibility of asymmetric adjustment costs. It may be simpler to reduce capital by increasing dividends or by buying back equity than by raising capital.
} 


\section{Equation of reinsurance}

Table 5 also presents the estimation results for the equation of the ratio of reinsurance. The chisquare statistic is significant at the $1 \%$ level, illustrating the validity of the estimation. Positive adjustments of risk-taking or capital generate an increase in the ratio of reinsurance. Unlike the inverse effect, we find that capital is not a substitute for reinsurance. This result can be explained by the fact that the marginal cost of reinsurance per unit of risk is less than that for capital, creating an asymmetric relationship. Another explanation may lie in the imperfect substitutability between the two mechanisms in the sense that reinsurance can play the same role as capital, whereas the reverse is not the case. For example, capital does not reduce the volatility of losses.

Moreover, the results show that the partial adjustment factor is not significant and illustrate that the reinsurance policy does not converge toward a long-run target level.An increase in inefficiency positively affects the level of reinsurance. Consistent with the findings of Cole and McCullough (2006), diversified firms use less reinsurance. Moreover, stock firms appear to use less reinsurance than mutual firms. This result supports the idea that stock firms have easier access to external funding and are less risk averse than mutuals. The size variable, which can be associated with diversification, is significant and negative. Accordingly, large firms tend to have better risk allocation and use less reinsurance. The introduction of regulatory pressures does not change the pattern of results.

\section{Equation of Risk}

The last part of Table 5 presents the estimation results for the risk equation. The chi-square statistic is significant at the 0.001 level. A positive capital adjustment leads to lower risk. We also note the asymmetric relationship between capital and risk adjustment, which can be explained by the lagged effect of capital on risk.

Moreover, we note that a positive adjustment of reinsurance increases this risk. This finding is consistent with the view of Shiu (2011) and Aunon-Nerin and Ehling (2008), who report that the heavy use of reinsurance leads to high risk-taking. The partial adjustment factor is not significant, indicating that risk-taking does not converge to a long-run target. The Mix and Hibl variables, which reflect the degree of concentration of the main underwriting branches and lines of business, are positive and significant. As the activities of the company become more concentrated, the company's risk-taking increases in the short term. Insurers with a low level of efficiency are more prone to high risk-taking than insurers with greater cost efficiency. As expected, size encourages risk-taking, which is more prevalent among stock firms than among mutual firms. 
Table 5. Estimation results of the simultaneous equations using volatility as a risk measure

\begin{tabular}{|c|c|c|c|c|c|c|c|c|c|c|c|c|}
\hline & & & & écificatio & & & & & Spécifi & ition II & & \\
\hline & & $\Delta \mathrm{Cap}_{t}$ & & AReins $s_{t}$ & & & & $a p_{t}$ & & ins $_{t}$ & & $\Delta$ Riskl $_{t}$ \\
\hline & Coef & $t$-stat & Coef & $t$-stat & Coef & t-stat & Coef & $t$-stat & Coef & t-stat & Coef & t-stat \\
\hline$\Delta C_{a p}$ & & & $0.570^{* * * t}$ & 3.82 & $-0.224^{* * t *}$ & -2.85 & & & $0.569^{* * *}$ & 3.75 & $-0.214^{50 *}$ & -2.71 \\
\hline$\Delta$ Reins $_{t}$ & $-0.155^{* * *}$ & -4.72 & & & $0.456^{* * *}$ & 12.53 & $-0.149^{* t * t}$ & -4.44 & & & $0.442^{* * *}$ & 11.96 \\
\hline$\Delta R i s k l_{t}$ & $0.216^{* *}$ & 2.36 & $2.133^{* * *}$ & 12.95 & & & $0.175^{*}$ & 1.93 & $2.184^{* * *}$ & 12.8 & & \\
\hline $\mathrm{Cap}_{t-1}$ & $-0.0519^{\text {t\#t }}$ & -2.73 & & & & & $-0.038^{* *}$ & -2 & & & & \\
\hline Reins $_{t-l}$ & & & -0.00997 & -1.00 & & & & & -0.0107 & -1.04 & & \\
\hline Riskl $_{t-l}$ & & & & & 0.0041 & 0.54 & & & & & 0.00379 & 0.47 \\
\hline $\operatorname{Reg}_{t-l}{ }^{*}{ }^{*} \operatorname{Cap}_{t-l}$ & & & & & & & & & $-0.358^{* * *}$ & -2.37 & $0.197^{* * * *}$ & 2.63 \\
\hline Reg $_{t-1} *$ Reins $_{t-1}$ & & & & & & & $0.049^{* * * *}$ & 3.34 & & & -0.0192 & -1.21 \\
\hline $\operatorname{Reg}_{t-1} * R_{i s k I_{t-l}}$ & & & & & & & 0.16 & 0.67 & 0.027 & 0.07 & & \\
\hline Perf & $0.544^{* * * *}$ & 5.84 & -0.0569 & -1.42 & & & $0.5325^{* * * *}$ & 25.37 & 0.0369 & 0.23 & & \\
\hline Cost_cap & $-0.0535^{*+* *}$ & -5.42 & & & & & $-0.0487^{* * * *}$ & -4.87 & & & & \\
\hline Catastrophe & -0.00403 & -0.20 & & & & & -0.00522 & -0.25 & & & & \\
\hline Assy & $0.0455^{* \star *}$ & 4.34 & & & & & $0.04567^{* * *}$ & 4.32 & & & & \\
\hline Lqt risk & $-0.0165^{* * * *}$ & -5.42 & & & & & $-0.0151^{* * * *}$ & -4.88 & & & & \\
\hline Cost_ineff & $0.0717^{\mathrm{s**}}$ & 8.61 & $0.147^{* * * *}$ & 2.93 & $-0.0738^{* * * *}$ & -2.81 & $0.0731^{* * *}$ & 9.03 & $0.20478^{* *}$ & 2.11 & $-0.075^{* * *}$ & -2.87 \\
\hline Reinsprice & & & $9.92 \mathrm{E}-08$ & 0.03 & & & & & $-8.49 \mathrm{E}-06$ & -0.08 & & \\
\hline Mix & & & $-0.411^{* * *}$ & -5.75 & $0.203^{* * * *}$ & 5 & & & $0.034^{\circ * 4 *}$ & 3.17 & $0.2142^{* * * * *}$ & 5.11 \\
\hline Loss_vol & & & 0.000323 & 0.65 & & & & & $0.0034^{\text {"*w }}$ & 2.1 & & \\
\hline lev & & & & & 0.000427 & 0.44 & & & & & 0.0004 & 0.52 \\
\hline Hibl & & & $-0.530^{* * *}$ & -5.13 & $0.254^{* * *}$ & 4.46 & & & 0.0299124 & 0.64 & $0.2673^{* * *}$ & 4.62 \\
\hline Higeo & & & -0.0377 & -0.73 & 0.0184 & 0.73 & & & -0.0149727 & -0.57 & 0.014 & 0.54 \\
\hline Growth & $-0.0309^{* * * *}$ & -12.56 & & & & & $-0.0313^{* * * *}$ & -12.85 & & & & \\
\hline Deficit & $-0.0933^{\text {thit }}$ & -13.35 & & & & & $-0.092^{* * \hbar k}$ & -13.23 & & & & \\
\hline Stock & 0.000992 & 0.59 & $-0.0675^{* n * *}$ & -4.43 & $0.0337^{*+1 * *}$ & 4.17 & 0.00114 & 0.71 & $-0.070^{* \omega * k}$ & -4.45 & $0.0346^{* w *}$ & 4.23 \\
\hline Group & $0.00441^{*+* *}$ & 2.66 & -0.0131 & -1.22 & 0.00653 & 1.19 & 0.00455 & 2.84 & -0.0150 & -1.37 & 0.0074 & 1.34 \\
\hline Size & -0.000879 & -1.35 & $-0.00839^{* * *}$ & -2.53 & $0.00412^{* * t}$ & 2.32 & -0.00055 & -0.84 & $-0.008^{\text {*ink }}$ & -2.61 & $0.0043^{* *}$ & 2.42 \\
\hline 2001.year & $-0.0142^{n+* * t}$ & -2.76 & $-0.124^{* * * *}$ & -6.31 & $0.0592^{* * * *}$ & 6.49 & $-0.012^{*+*}$ & -2.35 & $-0.128^{* * * *}$ & -6.38 & $0.0598^{* * *}$ & 6.56 \\
\hline 2002.year & $0.0133^{* *}$ & 2.57 & $0.0862^{\text {tht }}$ & 4.6 & $-0.040^{* * *}$ & -4.60 & $0.01171^{* *}$ & 2.3 & $0.0884^{* * * *}$ & 4.63 & $-0.040^{\mathrm{kt*k}}$ & -4.61 \\
\hline 2003.year & $0.0251^{* 2 * *}$ & 8.76 & -0.0253 & -1.52 & 0.0111 & 1.28 & $0.0258^{\text {***t }}$ & 9.25 & -0.0247 & -1.46 & 0.01046 & 1.21 \\
\hline 2004.year & $0.0148^{* 2 *}$ & 5.33 & -0.0159 & -0.97 & 0.00696 & 0.82 & $0.01576^{\text {kt*k }}$ & 5.79 & -0.0165 & -0.99 & 0.00701 & 0.83 \\
\hline 2005.year & $0.0166^{* * *}$ & 5.46 & -0.0106 & -0.57 & 0.00459 & 0.48 & $0.0173^{* * * *}$ & 5.88 & -0.01047 & -0.56 & 0.00436 & 0.46 \\
\hline 2006.year & $0.0216^{* * *}$ & 7.14 & -0.0128 & -0.69 & 0.00525 & 0.55 & $0.0222^{* * * *}$ & 7.55 & -0.01212 & -0.64 & 0.00468 & 0.49 \\
\hline 2007.year & $0.0154^{* * *}$ & 5.3 & -0.0036 & -0.20 & 0.00135 & 0.14 & $0.0157^{* \pm *}$ & 5.61 & -0.00372 & -0.2 & 0.00133 & 0.14 \\
\hline Intercept & 0.02 & 0.91 & $0.566^{\text {*** }}$ & 4.88 & $-0.274^{* * *}$ & -4.18 & 0.006464 & 0.29 & $0.602^{* * k t}$ & 4.91 & $-0.286^{* * * t}$ & -4.3 \\
\hline Chi-2 & & 36.9 & & 297.3 & & & 285 & & 281.48 & & & 1.17 \\
\hline$P$-value & & 0 & & 0 & & & ( & & 0 & & & 0 \\
\hline Hansen-Sarg & n statistic & & & .197 & & & & & 46.812 & & & \\
\hline$P$-value & & & & 0.3305 & & & & & 0.2131 & & & \\
\hline
\end{tabular}

This table reports the results of the $3 S L S$ estimation for the full sample, without (specification I) and with (specification II) interaction terms. *,**, *** represent statistical significance at 10\%, 5\% and 1\% levels, respectively. The Hansen-Sargan test evaluates the validity of the instruments. 
Table 6. Estimation results following the capital level

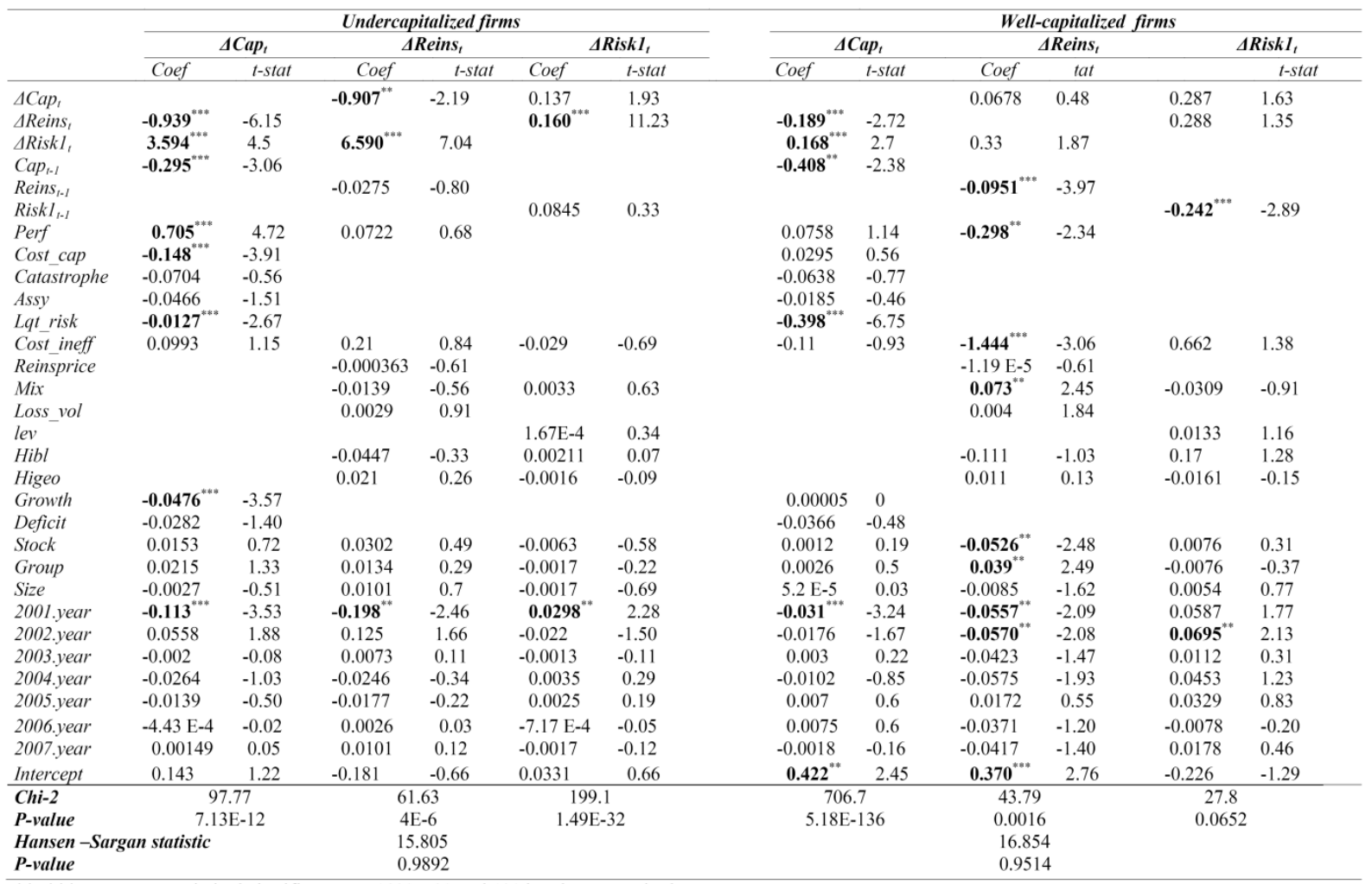

This table reports the results of the $3 S L S$ estimation following the buffer level. *, **, and *** represent statistical significance at $10 \%$, $5 \%$, and $1 \%$ levels, respectively. The Hansen-Sargan test evaluates the validity of the instruments.

\subsection{Sub-sample estimation}

To reduce the effect of sample heterogeneity and the aggregation bias that it implies, we divided the overall sample into several sub-samples. The first sub-sample is based on the level of capital held beyond the regulatory minimum. We first estimate a new regression using a sample of the bottom third of firms in terms of the ratio of capital to the regulatory minimum. The threshold obtained for the first sub-sample was 2.41. Thus, this sub-sample includes all insurers that have almost 2.5 times the minimum capital requirement. The estimation results, reported in Table 6 , illustrate that the relationship between capital adjustment and risk remains positive. The coefficient is significant with a relatively high value, indicating a high sensitivity of the ratio of capital to risk. Adjustments to the level of reinsurance appear to have a greater impact on capital. Reinsurance is a perfect substitute for capital for these companies. The capital ratio is the only variable that converges to a long-term level, with the speed of adjustment in this sub-sample greater than that observed in the overall sample. The second part of the table shows the top third of most capitalized insurers, with a threshold of 5.65. We observe a positive fit in the relationship between capital and risk, although it is less than that observed for small-cap companies. Partial adjustment factors of the endogenous variables are all significant. These results can be explained by the fact that insurers have significant flexibility in their funding sources, which allows them to achieve their goals through different financial policies. The sample is divided into two sub-groups by the value of assets corresponding to the top and bottom thirds. The results presented in Table 7 generally confirm those obtained with the total sample, except for the relationship between capital and risk for major insurance companies, a relationship that is negative in both directions. A final estimation is performed by dividing the sample into mutual and stock companies. The results, presented in Table 8, confirm our hypotheses. The results for the other explanatory variables are also affected by the organizational form. 
Table 7. Estimation results for stock and mutual firms

\begin{tabular}{|c|c|c|c|c|c|c|c|c|c|c|c|c|}
\hline & \multicolumn{6}{|c|}{ Small firms } & \multicolumn{6}{|c|}{ Large firms } \\
\hline & \multicolumn{2}{|c|}{$\Delta \operatorname{Cap}_{t}$} & \multicolumn{2}{|c|}{ AReins $_{t}$} & \multicolumn{2}{|c|}{$\Delta$ RiskI $_{t}$} & \multicolumn{2}{|c|}{$\Delta$ Cap $_{t}$} & \multicolumn{2}{|c|}{$\operatorname{AReins}_{t}$} & \multicolumn{2}{|c|}{$\Delta$ RiskI $_{t}$} \\
\hline & Coef & $t$-stat & Coef & t-stat & Coef & t-stat & Coef & t-stat & Coef & $t$-stat & Coef & $t$-stat \\
\hline$\triangle \mathrm{Cap}_{t}$ & & & $0.355^{* *}$ & 2.45 & -0.1100 & -0.99 & & & $1.249^{*+* z}$ & 3.47 & $-0.314^{* *}$ & -2.42 \\
\hline AReins, & $-0.08^{*}$ & -1.66 & & & $0.514^{k * t *}$ & 8.97 & $-0.191^{\text {*ank }}$ & -3.06 & & & $0.323^{N * * *}$ & 7.79 \\
\hline$\triangle$ ARiskI, & $0.37356 *$ & 2.39 & $1.752^{* * * *}$ & 13.31 & & & $-0.269^{*}$ & -1.88 & $2.905^{n+* *}$ & 5.85 & & \\
\hline $\operatorname{Cap}_{t-1}$ & -0.0424 & -1.15 & & & & & -0.01097 & -0.39 & & & & \\
\hline Reins $_{t-l}$ & & & $-0.039^{* * z}$ & -2.82 & & & & & -0.0040 & -0.17 & & \\
\hline RiskI I $_{t-l}$ & & & & & -0.0076 & -0.49 & & & & & -0.0125 & -0.31 \\
\hline $\operatorname{Reg}_{t-1} * \operatorname{Cap}_{t-1}$ & & & -0.1530 & -1.01 & 0.1435 & 1.4 & & & -0.3444 & -1.15 & 0.1029 & 0.77 \\
\hline Reg $_{t-1} *$ Reins $_{t-1}$ & 0.0512 & 1.59 & & & -0.0484 & -1.5 & 0.0175 & 0.77 & & & -0.0084 & -0.22 \\
\hline $\operatorname{Reg}_{t-l} * R_{i s k I_{t-1}}$ & 0.3843 & 0.79 & 0.2146 & 0.34 & & & $2.930^{* * * z}$ & 3.04 & -0.3164 & -0.12 & & \\
\hline Perf & $0.4685^{N . * *}$ & 15.63 & -0.0413 & -1.2 & & & $0.4299^{* * * * t}$ & 12.08 & -0.2390 & -1.76 & & \\
\hline Cost_cap & -0.025 & -1.5 & & & & & $-0.0260^{\prime \prime}$ & -1.94 & & & & \\
\hline Catastrophe & 0.0461 & 0.36 & & & & & 0.0241 & 0.86 & & & & \\
\hline Assy & $0.0566^{* * * *}$ & 2.7 & & & & & $0.0501^{* *+*}$ & 3.47 & & & & \\
\hline Lqt risk & $-0.02588^{* * * *}$ & -3.32 & & & & & $-0.009^{* * * * *}$ & -3.2 & & & & \\
\hline Cost_ineff & $0.0697^{* * * *}$ & 4.64 & $0.323^{* * * *}$ & 5.09 & $-0.2^{* * * *}$ & -4.18 & $0.0904^{* * * *}$ & 6.3 & -0.0055 & -0.06 & -0.0099 & -0.3 \\
\hline Reinsprice & & & 0.00001" & 1.65 & & & & & 0.0000 & 1.12 & & \\
\hline Mix & & & $-0.344^{\omega * * *}$ & -4.26 & $0.262^{* \cdots *}$ & 3.68 & & & -0.1718 & -1.27 & 0.0388 & 0.78 \\
\hline Loss_vol & & & 0.0008 & 0.9 & & & & & -0.0006 & -0.37 & & \\
\hline lev - on & & & $-0.264^{\text {***t* }}$ & -2.79 & 0.0043 & 1.62 & & & $-0.447^{* * *}$ & -1.98 & 0.0002 & 0.15 \\
\hline Hibl & & & 0.0873 & 1.05 & $0.162^{* * * *}$ & 2.37 & & & -0.0184 & -0.24 & 0.1281 & 1.48 \\
\hline Higeo & & & & & -0.089 & -1.54 & & & & & -0.0010 & -0.03 \\
\hline Growth & $-0.150^{* * *}$ & -10.59 & & & & & $-0.042^{* * * t}$ & -7.46 & & & & \\
\hline Deficit & 0.00083 & 0.26 & & & & & -0.012 & -1.4 & & & & \\
\hline Stock & 0.0041 & 1.33 & $-0.112^{n+w z}$ & -4.13 & $0.084^{k * w w}$ & 3.75 & 0.0008 & 0.33 & 0.0010 & 0.15 & 0.0015 & 0.22 \\
\hline Group & 0.0024 & 0.89 & -0.0144 & -1.15 & 0.012 & 1.38 & 0.0039 & 1.33 & -0.0050 & -0.28 & 0.0053 & 0.64 \\
\hline Size & -0.0009 & -0.18 & $0.014^{*}$ & 1.76 & $-0.011^{*}$ & -1.92 & -0.0010 & -1.1 & -0.0151 & -0.73 & -0.0005 & -0.18 \\
\hline 2001.year & 0.0008 & 0.16 & $-0.039^{*}$ & -1.82 & $0.026^{*}$ & 1.74 & 0.0234 & 1.5 & $-0.301^{* * * *}$ & -4.81 & $0.103^{* * t * x}$ & 8.89 \\
\hline 2002year & $0.0285^{* * * *}$ & 4.39 & -0.0035 & -0.16 & 0.0042 & 0.28 & -0.027 & -1.56 & $0.337^{* \infty * *}$ & 5.29 & $-0.115^{* * * *}$ & -9.85 \\
\hline 2003year & $0.0199^{* * * *}$ & 3.35 & 0.0013 & 0.06 & -0.002 & -0.13 & $0.024^{* * * *}$ & 5.49 & -0.0157 & -0.56 & 0.0021 & 0.19 \\
\hline 2004.year & $0.0201^{n * * *}$ & 3.17 & -0.0101 & -0.46 & 0.0051 & 0.33 & $0.0124^{n+3 * t}$ & 3.01 & -0.0099 & -0.38 & 0.0017 & 0.16 \\
\hline 2005year & $0.0226^{* * * *}$ & 3.5 & 0.0065 & 0.27 & -0.0036 & -0.21 & $0.0140^{* * * * *}$ & 3.04 & -0.0052 & -0.18 & 0.0004 & 0.03 \\
\hline 2006.year & $0.0159^{* * * *}$ & 2.57 & -0.0103 & -0.42 & 0.0046 & 0.27 & $0.0244^{* \omega * *}$ & 5.35 & -0.0095 & -0.31 & 0.0012 & 0.1 \\
\hline 2007.year & -0.035 & -0.53 & -0.0006 & -0.02 & 0.0005 & 0.03 & $0.0164^{* * * *}$ & 3.82 & -0.0043 & -0.15 & 0.0001 & 0.01 \\
\hline Intercept & $-0.1502^{*+1 * *}$ & -10.59 & 0.0193 & 0.13 & 0.0135 & 0.14 & -0.00071 & -0.03 & 0.2182 & 1.03 & -0.0495 & -0.58 \\
\hline Chi-2 & 1082 & & 261. & & 135 & & 755.5 & & 73.19 & & 471.84 & \\
\hline P-value & 0 & & 0 & & 0 & & 0 & & 0 & & 0 & \\
\hline \multirow{2}{*}{\multicolumn{3}{|c|}{$\begin{array}{l}\text { Hansen-Sargan statistic } \\
\text { P-value }\end{array}$}} & \multirow{2}{*}{\multicolumn{2}{|c|}{$\begin{array}{l}37.646 \\
0.576\end{array}$}} & & & & & 47.07 & & & \\
\hline & & & & & & & & & 0.205 & & & \\
\hline
\end{tabular}

This table reports the results of the $3 S L S$ estimation for stock and mutual firms. *, **, and *** represent statistical significance at 10\%, $5 \%$, and $1 \%$ levels, respectively. The Hansen-Sargan test evaluates the validity of the instruments. 
Table 8. Estimation results for small and large firms

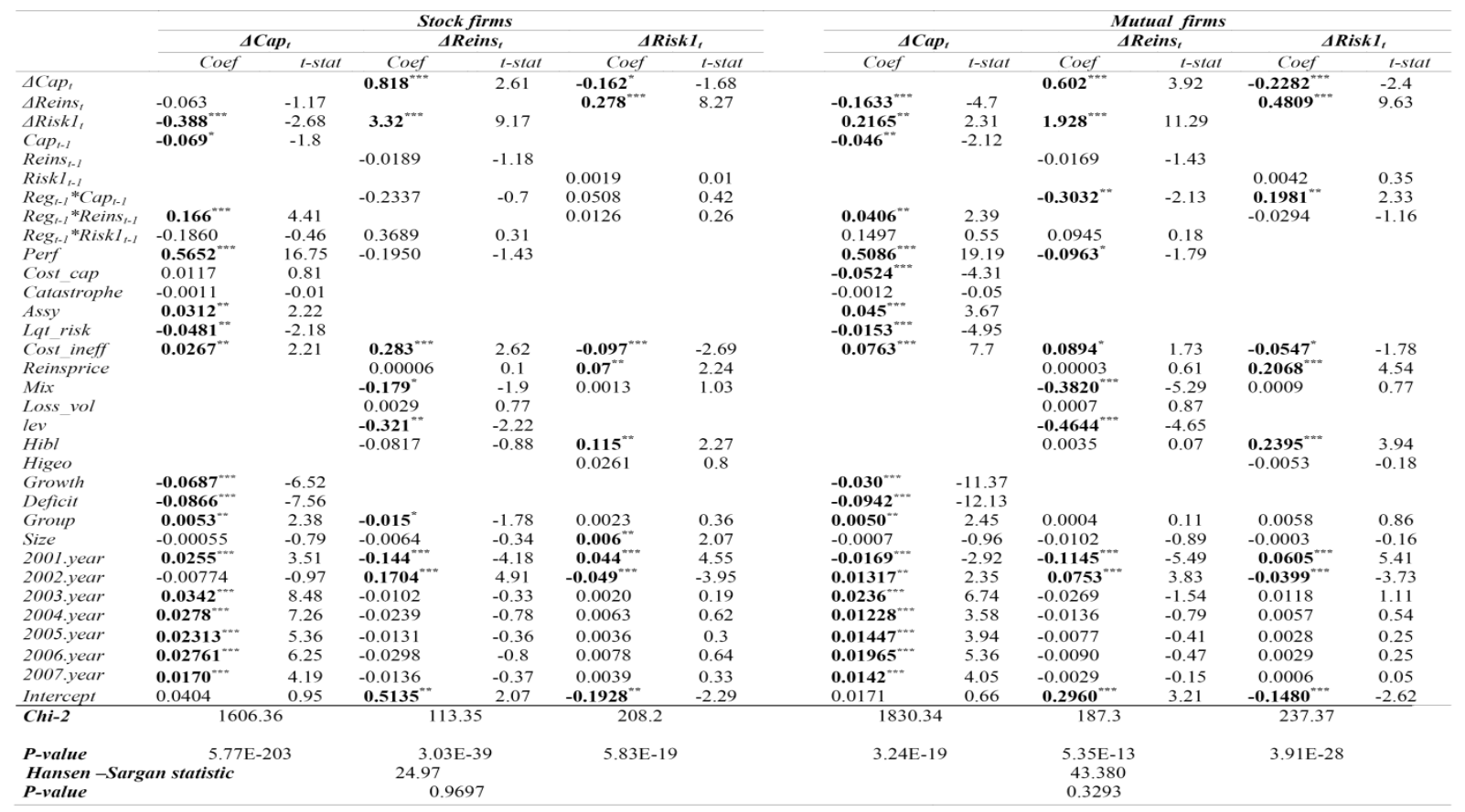

This table reports the results of the $3 S L S$ estimation for small and large firms. ** **, and *** represent statistical significance at $10 \%$, $5 \%$, and $1 \%$ levels, respectively. The Hansen-Sargan test evaluates the validity of the instruments.

Table 9. Estimation results of the simultaneous equations using the $\mathrm{RBC}$ ratio as a risk measure

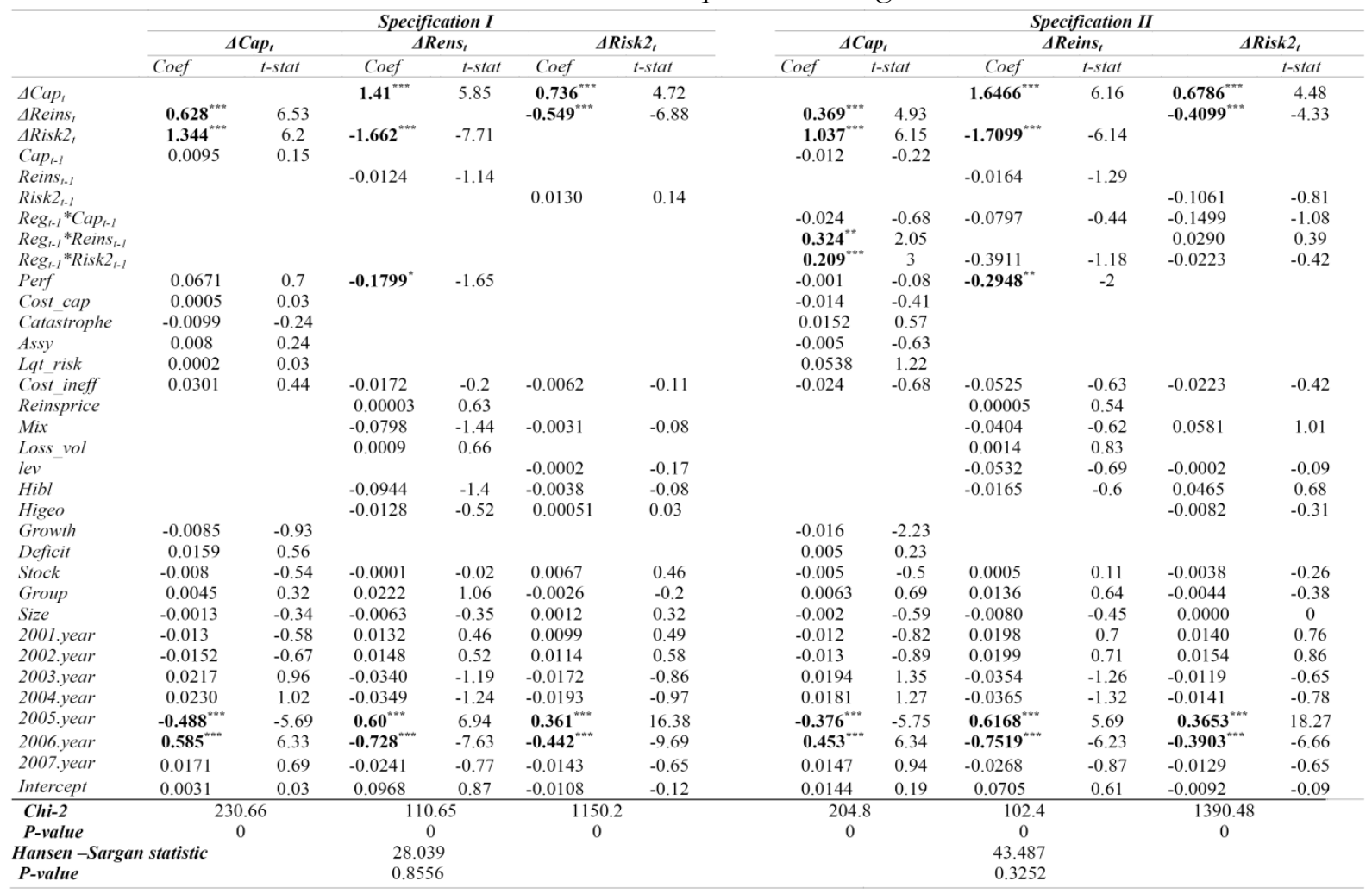

This table reports the results of the $3 S L S$ estimation following the buffer level. *, **, and *** represent statistical significance at 10\%, $5 \%$, and $1 \%$ levels, respectively. The Hansen-Sargan test evaluates the validity of the instruments. 


\subsection{Robustness checks}

In this section, we conduct additional robustness tests, covering other aspects of the empirical study, such as risk measurement, the sample structure, and the choice of instrumental variables. Unlike capital and reinsurance measures, which have straightforward definitions, risk assessment remains an open issue. Several measures have been proposed in the literature, for example, the standard deviation of the loss ratio (De Hass et al. 2010, Meyers 1989; Guo and Winter, 1997) and an insurer's exposure to external factors as captured by market betas (Eling and Schuhmacher, 2007). Equity volatility reflects both external and firm-specific factors (systematic and unsystematic risk). In contrast, Myers and Read (2001) propose the default ratio. An alternative measure is the ratio of regulatory capital RBC. Similar to Chen et al. $\left(2012^{a}\right)$, we provide new estimates of the model presented above using this alternative risk measure. The results reported in Table 9 confirm those initially obtained. The relationships remain significant in all cases, although in some cases, the signs differ from cases where risk is measured by volatility. The results can be explained in terms of the various criticisms of the RBC system.

The second robustness test is related to the sample structure. Indeed, we use an unbalanced panel so that the final sample contains missing values that may affect the quality of the results. This consideration is especially important when there are several consecutive values missing in the sample. To resolve this issue, we introduce a data screen requiring that an insurer appear in the sample for at least $k$ consecutive periods. This condition was not applied in the original sample. For example, for $k$ up to six, all interactions remain significant. Similarly, with $\mathrm{k}$ greater than six, some of the adjustment relationships become insignificant. A third robustness test concerns the choice of instruments, an important step in the estimation process. There are a number of instruments for which the results are stable. For example, the deviation of earnings over the medium term, the size of the business over the last five years and the average loss, as proposed by Shim (2010), are valid instruments.

\section{Conclusion}

This paper analyzes the short-run interactions between capital, reinsurance, and risk-taking for property-liability insurance firms. We develop a system of simultaneous equations to identify the potential links between these variables while controlling for endogeneity. The main objective of this paper is to determine how changes in capital levels impact the other decision variables, reinsurance, and risk-taking, and vice versa. A second objective of this research is to analyze the long-run trajectories of these policies. Such issues are of particular importance for regulators interested in how insurers will respond to given prudential rules. The sample size was sufficient to conduct an effective empirical analysis. The results are consistent with our theoretical hypotheses overall, highlighting the existence of significant relationships between the key variables and supporting the view that they are jointly determined. In their efforts to maximize firm value, insurers simultaneously adjust the various decision variables. The short-run adjustments between risk and capital are positive, providing interesting insights into the effects of regulation on insurer behavior. In contrast, reinsurance is negatively associated with capital, for which it acts as a substitute. The capital ratio slowly converges to a long-run target and can thus be viewed as a leading decision variable, reflecting insurers' priorities.

Regulatory pressures play an active role in moderating risk-taking and capital toward acceptable levels. Short-run adjustments depend on the level of capital held in excess of the minimum requirement. Weakly capitalized insurers reconstruct a buffer level of capital by raising capital and reducing risk. In contrast, adequately capitalized insurers maintain their capital reserves and increase both their risk and reinsurance levels. For these firms, higher capital ratios may prevent moral hazard and mitigate informational frictions between policyholders and shareholders. However, these results cannot tell us whether insurers operate efficiently. 


\section{Appendix 1}

The observed changes in the insurer's capital, reinsurance, and risk levels are the sum of two components, a discretionary adjustment and a change caused by factors exogenous to the insurer. Formally, the equations are as follows:

$$
\begin{gathered}
\Delta \operatorname{Cap}_{i, t}=\varphi_{B u f} \Delta \operatorname{Cap}_{i, t-1}^{d}+v_{i, t} \\
\Delta \operatorname{Reins}_{i, t}=\varphi_{\text {Reins }} \Delta \operatorname{Reins}_{i, t-1}^{d}+u_{i, t} \\
\Delta \operatorname{Risk}_{i, t}=\varphi_{\text {Risk }} \Delta \operatorname{Risk}_{i, t-1}^{d}+e_{i, t}
\end{gathered}
$$

where $\Delta \operatorname{Cap}_{i, t}, \Delta$ Reins $_{i, t}$, and $\Delta$ Risk $_{i, t}$ are the observed changes in capital, reinsurance, and risk levels, respectively, for insurer $i$ in period $t$. The variables $\Delta$ Cap $_{i, t-1}^{d}, \Delta \operatorname{Reins}_{i, t-1}^{d}$, and $\Delta \operatorname{Risk}_{i, t-1}^{d}$ represent discretionary adjustments in capital and risk, whereas $v_{i, t}, \boldsymbol{u}_{i, t}$, and $\boldsymbol{e}_{i, t} \mu_{i, t}$ are exogenous adjustments to capital, reinsurance, and risk, respectively. The partial adjustment model supposes that insurers may not be able to adjust their desired capital, risk, and reinsurance levels instantaneously. Thus, discretionary changes are proportional to the differences between target levels and the levels existing in period $t-1$ :

$$
\begin{aligned}
\Delta \operatorname{Cap}_{i, t}^{d} & =\varphi_{\text {Cap }}\left(\operatorname{Cap}_{i, t}^{*}-\operatorname{Cap}_{i, t-1}\right) \\
\Delta \operatorname{Reins}_{i, t}^{d} & =\varphi_{\text {Reins }}\left(\operatorname{Reins}_{i, t}^{*} \text {-Reins }_{i, t}\right) \\
\Delta \operatorname{Risk}_{i, t}^{d} & =\varphi_{\text {Risk }}\left(\operatorname{Risk}_{i, t}^{*}-\operatorname{Risk}_{i, t-1}\right)
\end{aligned}
$$

The coefficients $\varphi_{\text {Cap }}, \varphi_{\text {Reins }}$, and $\varphi_{\text {Risk }}$ measure speeds of adjustments. Cap ${ }_{i, t}^{*}$, Reins ${ }_{i, t}^{*}$, and Risk ${ }_{i, t}^{*}$ are target capital, risk, and reinsurance levels, respectively. Substituting equations (A.4), (A.5), and (A.6) into (A.1), (A.2), and (A.3) yields the following:

$$
\begin{aligned}
& \Delta \operatorname{Cap}_{i, t}=\varphi_{\text {Cap }}\left(\operatorname{Cap}_{i, t}^{*}-\operatorname{Cap}_{i, t-1}\right)+v_{i, t} \\
& \Delta \text { Reins }_{i, t}=\varphi_{\text {Reins }}\left(\text { Reins }_{i, t}^{*}-\text { Reins }_{i, t-1}\right)+u_{i, t} \\
& \Delta \text { Risk }_{i, t}=\varphi_{\text {Risk }}\left(\text { Risk }_{i, t}^{*}-\text { Risk }_{i, t-1}\right)+e_{i, t}
\end{aligned}
$$

The target levels of capital, risk, and reinsurance for an insurer are not observable. As in Flannery and Rangan (2006), Rime (2001), and Shim (2010), these target levels may differ across insurers or over time and depend on the insurer's specific characteristics (Shim, 2010). Thus, the target levels of capital, risk, and reinsurance for an insurer can be written as follows:

$$
\begin{gathered}
\operatorname{Cap}_{i, t}^{*}=\rho \cdot X_{i, t} \\
\text { Reins }_{i, t}^{*}=\omega \cdot Y_{i, t} \\
\operatorname{Risk}_{i, t}^{*}=\theta \cdot Z_{i, t}
\end{gathered}
$$

Substituting equations (A.13), (A.14), and (A.15) into (A.10), (A.11), and (A.12), we obtain this final form of the model:

$$
\begin{aligned}
& \Delta \operatorname{Cap}_{i, t}=-\varphi_{\text {Cap }} \operatorname{Cap}_{i, t-1}+\varphi_{\text {Cap }} \rho . X_{i, t}+v_{i, t} \\
& \Delta \text { Reins }_{i, t}=-\varphi_{\text {Reins } \text { Reins }_{i, t-1}+\varphi_{\text {Reins }} \omega . Y_{i, t}+u_{i, t}} \\
& \Delta \text { Risk }_{i, t}=-\varphi_{\text {Risk }} \text { Risk }_{i, t-1}+\varphi_{\text {Risk }} \text { O. } Z_{i, t}+e_{i, t}
\end{aligned}
$$




\section{References}

- Adams, M., 1996. The Reinsurance Decision in Life Insurance Firms: An Empirical Test of the Risk-Bearing Hypothesis. Accounting and Finance, 36: 15-30.

- Adams, M., Hardwick, F. and Zou, H., 2008. Reinsurance and Corporate Taxation in the United Kingdom Life Insurance Industry. Journal of Banking and Finance, 32: 101-115.

- Adiel, R., 1996. Reinsurance and the management of regulatory ratios and taxes in the property-casualty insurance industry. Journal of Accounting and Economics, 22(1-3), 207-240.

- Aggarwal, R. and Jacques, K.T., 2001. The impact of FDICIA and prompt corrective action on bank capital and risk: Estimates using a simultaneous equations model. Journal of Banking and Finance, 25: 1139-1160.

- Altunbas, Y., Carbo, S., Gardener, E. and Molyneux, P., 2007. Examining the relationships between capital, risk and efficiency in European banking. European Financial Management, 13(1): 49-70.

- Armstrong J. and Dror D.M., 2006. Do micro health insurance units need capital or reinsurance? A simulated exercise to examine different alternatives. The Geneva Papers, 31: 739761

- Aunon-Nerin, D. and Ehling, P., 2008. Why Firms Purchase Property Insurance. Journal of Financial Economics, 90: 298-312.

- Ayuso, J., Perez, D. and Saurina, J., 2004. Are capital buffers pro-cyclical? Evidence from Spanish panel data. Journal of Financial Intermediation,13: 249-64.

- Baltagi, B.H., 2005. Econometric Analysis of Panel Data. (third ed.) John Wiley. \& Sons.

- Baranoff, E.G. and Sager, T.W., 2002. The relations among asset risk, product risk, and capital in the life insurance industry. Journal of Banking and Finance, 26(6): 1181-1197.

- Baranoff, E., Thomas W.S. and Papadopoulos, S., 2007. Capital and Risk Revisited: A Structural Equation Model Approach for Life Insurers. The Journal of Risk and Insurance, 74(3): 653-681.

- Bartram, S.M., Brown, G.W. and Fehle, F.R., 2009. International Evidence on Financial Derivatives Usage. Financial Management, 2: 185-206.

- Berger, A.N., 1995. The relationship between capital and earnings in banking'. Journal of Money, Credit, and Banking, 27(2): 432-56.

- Berger, A.N. and Mester, L.J., 1997. Inside the black box: What explains differences in the efficiency of financial institutions. Journal of Banking and Finance, 21, 895-947.

- Borde, S. F., Chambliss, K. and Madura, J., 1994. Explaining variation in risk across insurance companies. Journal of Financial Services Research, 8(3), 177-191.

- Campello, M., 2002. Internal Capital Markets in Financial Conglomerates: Evidence from Small Bank Responses to Monetary Policy, Journal of Finance, 57(6): 2773-2805.

- Carayannopoulos, P. and Kelly, M., 2004. Determinants of Capital Holdings: Evidence from the Canadian Property/casualty Insurance Industry. Journal of Insurance Regulation, 23(2):45-65.

- Chen, Y., Hamwi, I.S. and Hudson, T., 2001. The Effect of Ceded Reinsurance on Solvency of Primary Insurers. International Advances in Economic Research, 7: 65-82. 
- Cheng J. and Weiss, M.A., 2012. The Impact of RBC Requirements in Property-Liability Insurance », Working Paper, Shanghai Jiao Tong University.

- Cole, C.R. and McCullough, K.A., 2006. A Reexamination of the Corporate Demand for Reinsurance. Journal of Risk and Insurance, 73 (1): 169-192.

- Cummins J.D. and Sommer D.W., 1996. Capital and risk in property-liability insurance markets .Journal of Banking and Finance, 20: 1069-1092.

- Cummins, J.D. and Song, Q., 2008. Hedge The Hedgers: Usage Of Reinsurance And Derivatives By PC Insurance Companies. Working Paper, Temple University.

- Cummins, J.D. Phillips, R.D. and Smith, S.D., 2001. Derivatives and corporate risk management: Participation and volume decisions in the insurance industry. Journal ofRisk and Insurance, 68 (1), 51-91.

- Cummins, J.D. and Nini, G.P., 2002. Optimal capital utilization by financial firms: Evidence from the property-liability insurance industry. Journal of Financial Services Research, 21: 15-53.

- De Bie, T. and De Haan, L., 2007. Market timing and capital structure: evidence for Dutch firms. De Economist, 155(2): 183-206

- De Haan, L. andKakes, J., 2010. Are non-risk based capital requirements for insurance companies binding? .Journal of Banking and Finance, 34 (7): 1618-1627.

- Deng, S., Elyasiani, E. and Mao, C.X., 2007. Diversification and cost of debt of bank holding companies. Journal of Banking and Finance, 31: 2453-2473.

- Dionne, G. and Triki, T., 2004. On Risk Management Determinants: What Really Matters?.Working Paper, HEC Montreal.

- Eling, M. and Holzmüller, I., 2008. An Overview and Comparison of Risk-Based Capital Standards. Journal of Insurance Regulation, 26 (4): 31-60.

- Eling, M. and Schuhmacher, F., 2007. «Does the Choice of Performance Measure Influence the Evaluation of Hedge Funds?.Journal of Banking and Finance, 31: 2632-2647.

- Estrella, A., 2004. The cyclical behaviour of optimal bank capital. Journal of Banking and Finance, 28 (6): 1469-1498.

- Fama, E.F. and French, K.R., 2002. Testing trade-off and pecking order predictions about dividends and debt. Review of Financial Studies, 15: 1-33.

- Fonseca, A.R. and González, F., 2010. How bank capital vary across countries: The influence of cost of deposits, market power and bank regulation. Journal of Banking and Finance, 34: 892902.

- Frank, M.Z. and Goyal, V.K., 2009. Capital structure decisions: Which factors are reliabiy important?.Financial Management, 38: 1-38.

- Garven, J.R. and Lamm-Tennant, J., 2003. The Demand for Reinsurance: Theory and Empirical Tests. Insurance and Risk Management, 71: 217-238.

- Graham, J.R. and Rogers, D.A., 2002. Do Firms Hedge in Response to Tax Incentives?.Journal of Finance, 57: 815-839.

- Grubisic, E. and Leadbetter, D., 2007. The determinants of capital in the P\&C insurance industry. Working Paper, ARIA Annual Meeting Quebec City. 
- Harrington, S. E. and Niehaus, G., 2002. Capital Structure Decisions in the Insurance Industry: Stocks versus Mutuals. Journal of Financial Services Research,21: 145-163.

- Horiuchi, A., \& Shimizu, K., 2001). Did Amakudari undermine the effectiveness of regulator monitoring in Japan? Journal of Banking \& Finance, 25, 573-596.

- Hoerger, T.J., Sloan, F.A. and Hassan, M., 1990. Loss Volatility, Bankruptcy, and the Demand for Reinsurance. Journal of Risk and Uncertainty, 3: 221-245.

- Hughes, J.P. and Moon, C., 1997. Measuring bank efficiency when managers trade return for reduced risk. Working Paper, 199520, Rutgers University.

- Hughes, J.P., Lang, W. W. and Mester, L. J., 1996. Safety in number? Geographic diversification and bank insolvency risk. Working Paper, Federal Reserve Bank of Philadelphia.

- Jacques, K. and Nigro, P., 1997. Risk-Based Capital, Portfolio Risk, and Bank Capital: A Simultaneous Equation Approach. Journal of Economics and Business, 49: 533-547.

- Jensen M.C., 1986. Agency Costs of Free Cash Flow Corporate Finance and Takeovers. American Economic Review, 76(2):323-329.

- Jokipii, T. and Milne, A., 2011. Bank capital buffer and risk adjustment decisions1997. Journal of Financial Stability, 7(3): 165-178.

- Jokipii, T. and Milne, A., 2008. The cyclical behaviour of European bank capital buffers. Journal of Banking and Finance, 32(8): 1440-1451.

- Lamm-Tennant, J. and Starks, L., 1993. Stock versus Mutual Ownership Structures: The Risk Implications. Journal of Business, 66(1): 29-46.

- Lee, S.H. and Urrutia, J.L., 1996. Analysis and Prediction of Insolvency in the PropertyLiability Insurance Industry: A Comparison of Logit and Hazard Models. Journal of Risk and Insurance, 63 (1): 121-130.

- Liebenberg, A.P., Carson, J.M. and Dumm, R.E., 2010. A Dynamic Analysis of the Demand for Life Insurance, Social Science Research Network. Working Paper, http://papers.ssrn.com/sol3/papers.cfm?abstract id=1539609.

- MacMinn, R.D., 1987. Insurance and Corporate Risk Management. Journal of Risk and Insurance, 54: 658-677.

- Mayers D and Smith C.W., 1990. On the corporate demand for insurance: evidence from the reinsurance market .Journal of Business, 63:19-40

- Morgan, D.P., 2002. Rating banks: Risk and uncertainty in an opaque industry. American Economic Review, 92: 874-888.

- Myers S.C. and Majluf, N.S., 1984. Corporate Financing and Investment Decisions when Firms Have Information that Investors Do Not Have. Journal of Financial Economics, 13: $187-$ 221.

- Nocco, B.W. and Stulz, R.M., 1996. Enterprise Risk Management: Theory and Practice. Working Paper, http://papers.ssrn.com/sol3/papers.cfm?abstract id=921402.

- Plantin, G., 2006. Does Reinsurance Need Reinsurers?.Journal of Risk and Insurance, 73:153-168.

- Pottier, S.W. and Sommer, D.W., 2006. Opaqueness in the insurance industry: Why are some insurers harder to evaluate than others?.Risk Management and Insurance Review, 9: 149-163. 
- Powell, L.S., and Sommer, D.W., 2007. Internal Versus External Capital Markets in the Insurance Industry: The Role of Reinsurance. Journal of Financial Services Research, 31(2): 173189.

- Rime, B., 2001. Capital requirements and bank behaviour: empirical evidence for Switzerland. Journal of Banking and Finance, 25: 1137-1178.

- Saunders, A. and Cornett, M.M., 2007. Financial institutions management: A risk management approach. (6th edition). McGrraw-Hill Irwin Publisher.

- Scannella, E., 2012. Capital Regulation and Italian Banking System: Theory and Empirical Evidence. International Journal of Economics and Finance, 4 (2):

- Shim, J., 2010. Capital-based regulation, portfolio risk and capital determination: Empirical evidence from the US property-liability insurers. Journal of Banking \& Finance, 34: 2450 2461.

- Shiu, Y.M., 2011. Reinsurance and capital structure: evidence from the United Kingdom nonlife insurance industry. The Journal of Risk and Insurance, 78 (2) : 475-494

- Shortridge, R. and Avila, S., 2004. The Impact of Institutional Ownership on the Reinsurance Decision. Risk Management and Insurance Review, 7(2): 93-106.

- Shrieves, R. and Dahl, D., 1992. The Relationship Between Risk and Capital in Commercial Banks. Journal of Banking and Finance, 16: 439-457.

- Smith, C.W., 1977. Alternative methods for raising capital: rights versus underwritten offerings .Journal of Financial Economics, 5: 273-307.

- Stein, J.C., 1997. Internal Capital Markets and the Competition for Corporate Resources. Journal of Finance, 52(1): 111-133.

- Stulz R.M., 1996. Rethinking Risk Management. Journal of Applied Coporate Finance, 9(3): 8-24.

- Titman, S. and Wessels, R., 1988. The Determinants of Capital Structure Choice. Journal of Finance, 43: 1-19.

- Warner, J.B., 1977. Bankruptcy Costs: Some Evidence. Journal of Finance, 32: 337-347.

- Wells B.P., Cox, L.A. and Gaver, K.M., 1995. Free cash flow in the life insurance industry. Journal of Risk and Insurance, 62: 50-66.

- Williams, J., 2004. Determining management behavior in European banking. Journal of Banking and Finance, 28: 2427-2460.

- Zanjani, G. 2002. Pricing and Capital Allocation in Catastrophe Insurance. Journal of Financial Economics, 65(2): 283-305.

- Zou, H., and Adams, M.B., 2008. Debt Capacity, Cost of Debt, and Corporate Insurance. Journal of Financial and Quantitative Analysis, 43: 433-466. 